\title{
Can Analysts Assess Fundamental Risk and Valuation Uncertainty? An Empirical Analysis of Scenario-Based Value Estimates
}

\section{Citation}

Joos, Peter R., Joseph D. Piotroski, and Suraj Srinivasan. "Can Analysts Assess Fundamental Risk and Valuation Uncertainty? An Empirical Analysis of Scenario-Based Value Estimates." Journal of Financial Economics 121, no. 3 (September 2016): 645-663.

\section{Published Version}

http://www.sciencedirect.com/science/article/pii/S0304405X16300836

\section{Permanent link}

http://nrs.harvard.edu/urn-3:HUL.InstRepos:29660916

\section{Terms of Use}

This article was downloaded from Harvard University's DASH repository, and is made available under the terms and conditions applicable to Open Access Policy Articles, as set forth at http:// nrs.harvard.edu/urn-3:HUL.InstRepos:dash.current.terms-of-use\#OAP

\section{Share Your Story}

The Harvard community has made this article openly available.

Please share how this access benefits you. Submit a story.

\section{Accessibility}




\title{
Can Analysts Assess Fundamental Risk and Valuation Uncertainty? An Empirical Analysis of Scenario-Based Value Estimates
}

\author{
Peter Joos ${ }^{\text {a }}$ \\ Morgan Stanley \\ Joseph D. Piotroski \\ Stanford University \\ Suraj Srinivasan ${ }^{c^{*}}$ \\ Harvard Business School
}

March 10, 2014

\begin{abstract}
We use a dataset of sell-side analysts' scenario-based equity valuation estimates to examine whether analysts are able to assess the risk surrounding a firm's fundamental value. We find that the spread in analysts' state-contingent valuations captures the riskiness of operations and predicts the absolute magnitude of future long-run valuation errors and changes in firm fundamentals (i.e., maps into the distribution of one-year-ahead price outcomes and changes in operating performance). Additionally, analysts' assessment of fundamental risk and predictive ability systematically shifted during and after the financial crisis, consistent with the macro-economic shock raising awareness among analysts of their firms' systematic risk exposures.
\end{abstract}

JEL Classifications: G24, G11, G01

Keywords: Analysts; Fundamental Risk Assessment; Scenario-based Valuations; Target Prices

\footnotetext{
${ }^{a}$ Morgan Stanley Research, 20 Bank Street, Canary Wharf, Floor 06, London E14 4AD, Email: Peter.Joos@morganstanley.com

b Stanford University, Graduate School of Business, Knight Management Center, 655 Knight Way, Stanford, CA 94305, Phone: 650-498-6988, Email: jpiotros@stanford.edu

${ }^{\mathrm{c}}$ Harvard Business School, Soldiers Field, Boston, MA 02163, Phone: 617-495-6993, Email: ssrinivasan@hbs.edu

* The authors would like to thank Beth Blankespoor, Trevor Harris, Charles Lee, Maria Ogneva, Eric So, Guy Weyns and workshop participants at INSEAD, Stanford University, and the Harvard Business School IMO Conference for useful comments on this topic. The views of Peter Joos expressed in this paper are his own and do not necessarily represent the views of Morgan Stanley.
} 


\section{Can Analysts Assess Fundamental Risk and Valuation Uncertainty? An Empirical Analysis of Scenario-Based Value Estimates}

\section{Introduction}

This paper examines whether analysts are able to assess the uncertainty and state-contingent risk surrounding a firm's fundamental value. Prior research on analyst forecasting activity documents that their earnings forecasts, long term growth forecasts, stock recommendations, target prices, and investment reports both incorporate and convey new information about future earnings and firm value. ${ }^{1}$ Similarly, published assessments of equity securities' riskiness are predictive of daily excess price movements and convey information about the firms' sensitivity to Fama-French risk factors (Liu, Markov and Tamayo, 2007; 2012). In contrast, evidence about the quality of analysts' published valuations is mixed. Analysts' target price valuations convey information, as reflected by the market reaction to target price updates (Brav and Lehavy, 2003; Asquith, Mikhail and Au, 2005). However, these target prices are optimistic, extremely inaccurate and contain little long-run investment value. For example, Bradshaw, Brown and Huang (2013) find that the average stock underperforms the target price valuation by $15 \%$ over the forecast horizon, with an average absolute valuation error of $45 \%$ of current price. Similarly, less than half of all firms actually achieve the analyst's target price valuation over the twelve month forecast horizon (Asquith, Mikhail and Au, 2005). Thus, while much is known about analysts' ability to forecast mean payoffs, evidence on the individual analyst's ability to value firms, and gauge and communicate the risk and uncertainty surrounding the firm's long-term value, is scarce.

We address this gap in the literature by examining a unique set of state-dependent value estimates issued by sell-side analysts over the period January 2007 to December 2010 for a sample of US listed companies. Since January 1, 2007, company investment reports issued by Morgan Stanley analysts contain equity valuation estimates for three different economic scenarios: a base case, a bull case and a bear case scenario. ${ }^{2}$ This reporting process requires each team of analysts to supplement their target price forecasts with scenario-based value estimates that are dependent upon certain state-contingent factors occurring, such as a shift in market demand, change in competitive landscape, the impact of a new

\footnotetext{
${ }^{1}$ The existing literature on these topics is rich and vast. For a detailed review and discussion of the analyst forecasting literature, see Ramnath, Rock, and Shane (2008), and Beyer, Cohen, Lys and Walther (2010).

${ }^{2}$ Exceptions to this requirement are so-called Quick Comments that typically provide a short, timely commentary on market and company news events.
} 
product launch, regulatory change, a shift in macro-economic conditions, and a host of other economic events. This process creates a template by which analysts systematically assess, and inform their clients about, the jointly-determined risk factors and return potential surrounding the covered firm. Essentially, as the analyst outlines his/her beliefs about the firm's expected (i.e., base case) performance and value, he/she is also required to provide information that encapsulates the most likely alternative upside and downside valuation outcomes that could occur with reasonable probabilities. This reporting process creates a parsimonious, state-dependent distribution of valuation outcomes for each covered firm.

We use the data embedded in the distribution of scenario-based valuation forecasts - namely, the spread between the analyst's forecasted upside and downside valuations (normalized as a percentage of the base case valuation) - to measure the analyst's expectations about the magnitude of uncertainty and state-contingent risk surrounding the firm's fundamental valuation. Our first set of analyses document firm-level characteristics associated with the analyst's assessment of long-term valuation risk and uncertainty; our second set of analyses focus on whether analysts accurately assess this fundamental valuation risk by examining the distribution of base case valuation errors and ex post operating performance innovations conditional upon their ex ante spread in the firms' scenario-based value estimates. Together, these tests have the potential to either confirm or cast doubt upon individual analyst's ability to assess fundamental risk and uncertainty about the covered firm's long-term valuation.

We find that the magnitude of the spread embedded in the analyst's scenario-based value estimates is significantly associated with firm characteristics that capture the fundamental riskiness of the firm's operations and shareholder's equity (e.g., beta, small size, financial distress, losses, and idiosyncratic risk). This association is consistent with equity analysts considering firm-specific risk attributes when assessing state-contingent risk and creating scenario-based valuation models. We also find that the magnitude of these risk assessments is decreasing in the amount of analyst optimism embedded in the analyst's base case valuation forecast. This inverse relation suggests that an optimistic bias impacts the analyst's assessment of both the firm's expected payoff and the riskiness of that payoff.

In terms of predictive ability, we find that the magnitude of the spread across the analyst's scenario-based valuation estimates is positively related to the absolute magnitude of future long-run unanticipated return outcomes (i.e., absolute base case valuation errors). These predictive relations are robust to the exclusion of reports issued in advance of or during the height of the financial crisis period, 
incremental to commonly used measures of analyst disagreement about future performance (i.e., analyst forecast dispersion) and target price optimism, and various controls for innate firm characteristics at the report date. Moreover, the positive association between the spread in analyst valuations and absolute magnitude of future pricing errors is driven by analysts' ability to predict economic shocks to firm fundamentals -- ex ante valuation spreads are positively related to ex post changes in the covered firm's future financial performance (absolute changes in ROE, operating margin, and revenue growth), mirroring the relation between ex ante valuation spreads and long-run valuation errors. Essentially, a change in the state of the world manifests itself as a shock to the firm's fundamentals, which drives stock price and firm value away from the analyst's original base case valuation and towards an alternative bull case or bear case scenario reflected in the analyst's investment report.

Our final set of analyses examines analyst behavior around the recent financial crisis. Very little is known about how analysts' respond to macro-economic shocks or, more generally, assess and respond to variability in firm performance. We exploit the financial crisis as both an exogenous shock to firm fundamentals and a shift in the nature of risk affecting firm performance (from idiosyncratic to systemic). We use this unique setting to determine whether the manifestation of systemic, state-contingent risk impacts analysts' subsequent risk-return assessments. We find that the financial crisis systematically impacted both analysts' assessment of the risk-return tradeoff in their scenario-based valuations and the predictive nature of these valuations. First, we find that analysts ex ante assessments of state-contingent risk (i.e., the spread in their scenario-based valuations) widen during the crisis in response to the uncertainty created by the event. Second, and more importantly, analysts' assessments of state-contingent risk display a significantly stronger relation with the firm's systematic risk exposure (i.e., beta) and a significantly weaker relation with base case optimism after the event than before. While our evidence also suggests that the analysts maintained an optimism about expected returns during the crisis -expected (base case) performance in fact increased during the crisis period -- it would appear that the crisis seemingly brought considerations about risk to the forefront of the analysts' research efforts, with risk-return assessments made after the crisis placing a greater weight on the firm's systematic risk exposure. Finally, in terms of predictability, we find that the absolute magnitude of base case valuation errors are significantly smaller and more strongly correlated with the analysts' ex ante assessments of risk after the financial crisis than before. Together, the evidence suggests that analysts responded to the recent 
macro-economic shock by placing greater (less) emphasis on risk (non-risk, behavioral) factors in their scenario-based valuations, and that these changes improved their ability to assess both firm value and the firm's risk-return attributes.

Our paper provides several important contributions. First, we provide the first evidence on how analysts assess and incorporate state-contingent risk and outcome uncertainty into their valuation models through the use of new publicly available data. Our finding that analysts' scenario-based valuation estimates both reflect and convey information about the long-term risks and return potential affecting the value of the covered firm contributes to a small set of papers examining the ability of financial analysts to assess the riskiness of equity securities (e.g., Lui, Markov, and Tamayo, 2007; 2012). Second, our focus on the analyst's explicit assessment of the second moment of future one-year-ahead value outcomes, as captured by their reported distribution of scenario-based valuations, is novel to the literature. The longterm, state-dependent risk-reward assessments explored in this paper are both conceptually and empirically different than the categorical risk ratings, daily price volatility and factor loading outcomes explored in prior work. Moreover, by documenting a link between these ex ante assessments and ex post shocks to firm fundamentals, we provide clarity on the mechanism by which these risk assessments and future valuation errors are related. Third, by exploiting the financial crisis, we document how financial intermediaries respond to the revelation of risk and uncertainty created by large macro-economic shocks. The documentation of two complimentary effects - a greater emphasis on risk factors and the elimination of analyst optimism - supports behavioral arguments that judgments are influenced by the recency of past events. Fourth, we develop and examine a new empirical proxy for the level of uncertainty about a firm's fundamental value. This metric, the spread between bull and bear case valuation scenarios, is analystspecific (i.e., within-subject) and addresses concerns surrounding the use of another commonly used metric, analyst forecast dispersion (see Johnson, 2004), and is a better predictor of the distribution of future long-term price outcomes. Fifth, we document that the information contained in the distribution of scenario-based valuations is a better predictor of variance of long-term price outcomes than the categorical risk measure historically issued by the same analyst for the same firm. Lastly, the descriptive data presented in the paper raises questions about the influence of behavioral biases on an analyst's assessment of a firm's riskiness and return potential. 


\section{Background and motivation}

\subsection{Background on the Morgan Stanley Risk-Reward Framework}

The data used in our study are drawn from state-contingent valuation estimates made by Morgan Stanley analysts in their published investments reports. Weyns et al. (2007) describe Morgan Stanley's "risk-reward framework," the approach towards fundamental research that underpins the firm's equity investment analyses. ${ }^{3}$ In the traditional framework, analysts at most major brokerage firms provide equity investment recommendations (e.g., "buy", "hold", "sell") based principally upon the anticipated, or expected, appreciation or depreciation in the firm's stock price in the near term. These recommendations are supported by a single point target price forecast, frequently derived from a fundamentals-based analysis of the company's intrinsic value and its projected future cash flows. The risk-reward framework requires analysts to expand their analyses to present both bull and bear case valuation scenarios, in addition to the analyst's base case expectations for the company's stock price, over the following 12 months. ${ }^{4}$

To generate these three scenarios, the analysts are asked to extract information about firm risk from their fundamental analysis, with the goal of providing a "band of uncertainty" around the valuation of a particular stock. During this analysis, the analysts are expected to (1) identify a company's key business drivers; (2) identify the metrics affecting those drivers; and (3) predict the impact of likely changes in those metrics on target company performance and firm value. The three cases are expected to represent the full range of plausible outcomes over the forecast horizon. By mandating a state-contingent view of equity values, Morgan Stanley has created a standardized platform for their analysts to formally integrate fundamental risk and valuation uncertainty into their analysis.

To our knowledge, Morgan Stanley is the only sell-side equity research house that systematically provided this state-dependent valuation information in its research reports over the period studied. Weyns et al. (2007) argue that the framework better aligns Morgan Stanley's research product with its clients' thinking. They point out that the framework addresses what they call 'the fallacy of single-point estimates' in providing clients with a view on expected risk as well as expected returns. As such, the

\footnotetext{
${ }^{3}$ This section draws primarily from Srinivasan and Lane (2011).

${ }^{4}$ The base case valuation is analogous to the traditional "target price" which Morgan Stanley continues to provide to its clients, and to third-party aggregators of consensus estimates such as First Call, when conveying expectations about the firm's value.
} 
introduction of the framework served as a strategic initiative to differentiate Morgan Stanley's product from its competitors.

The framework provides a forward-looking measure of the firm's long-run risk-return tradeoff through the direct incorporation of "forward-looking, nuts-and-bolts information on the alternative paths that a company's value drivers might follow in the near to medium-term.” (Weyns et al. 2007; page 2). This risk-reward view of a stock includes "the analyst's choice of critical uncertainties, the assumptions underpinning various scenarios, and an implicit or explicit assessment of the relative likelihoods of different outcomes" (Weyns et al. 2007; page 5). The analysts are not, however, required to provide an explicit confidence interval within which the stock price is expected to fall with a given likelihood because a fundamentals-driven risk-reward approach does not produce a continuous probability distribution of value. Instead, analysts can present their conviction on their outlook by either tightening or loosening the range between bull and bear scenarios.

An example of the scenario-based valuation estimates created under the risk-return framework is presented in Appendix 2..$^{5}$ As illustrated in this excerpt from Morgan Stanley’s research report dated October 21, 2010 on Netflix, the analyst has forecasted a per-share value of the company's equity under three different economic scenarios, corresponding roughly to three alterative competitive outcomes for Netflix's business model and industry. The base case scenario reflects the analyst's most likely set of expectations for the company, in this instance, forecasting continued strength for the company's business model and continued growth. The bull case scenario estimates firm value conditional upon Netflix maintaining its strong competitive position and engaging in substantial international expansion. The bear case captures the risk associated with enhanced competition from digital download providers and kiosk vendors and associated margin compression. The output from analyst reports using this "risk-reward" framework forms the dataset used in our study.

\subsection{Related research and motivation}

Despite an early call for research on analyst's ability to assess firm risk (Zmijewski, 1993; page 337), such research is scare. This scarcity is driven by a lack of formal risk assessments in most analyst

\footnotetext{
${ }^{5}$ Appendix 2 comprises excerpts from research reports and should not be relied on as investment advice. This material is only as current as the publication date of the underlying Morgan Stanley research. For important disclosures, stock price charts and equity rating histories regarding companies that are the subject of the underlying Morgan Stanley research, see the Morgan Stanley Research Disclosure website at www.morganstanley.com/researchdisclosures.
} 
investment reports; however, historical exceptions exist. In the only set of published studies directly examining this issue, Lui et al. $(2007 ; 2012)$ examine risk ratings issued by Salomon Smith Barney and Citigroup over the period 1997-2003 and 1999-2006, respectively. ${ }^{6}$ Focusing on analysts' ability to assess and predict daily excess stock price volatility, Lui et al (2007) find that firm characteristics such as high leverage, high book-to-market ratio, low market capitalization, losses and lower earnings quality are significant determinants of the analysts' risk ratings, with idiosyncratic risk a more important determinant of analyst risk assessment than beta or illiquidity. They find that risk ratings explain around half of the cross sectional variation in future daily excess return volatility and that these ratings provide incremental information over and above other predictions future daily stock return volatility. Building on these findings, Lui et al (2012) examine the market's response to changes in Citigroup's equity risk ratings. The authors find strong evidence that changes in equity risk ratings, although infrequent in occurrence, convey significant new information to the market, both in absolute terms and relative to credit ratings changes. Moreover, changes in equity risk ratings are associated with a subsequent shift in Fama-French factor loadings, suggesting that analyst's revision conveyed timely information about a change in the firm's fundamental risk factors.

We view an analysis of analysts' state-contingent valuation estimates as a natural complement to, yet distinct from, the extant literature on risk ratings. First, assessing the firm's fundamental payoff risks and providing information about the potential distribution of long run, state-contingent valuation outcomes is fundamentally different from the act of assigning a categorical risk rating that comingles price and fundamental risk. This difference relates, principally, to the nature and horizon of the risk being assessed. The risk ratings historically employed by analysts seem to reflect both fundamental and price risk, and empirically, convey information about the degree of a firm's sensitivity to daily stock return volatility and/or various empirical risk factors. Given their focus on price volatility, the rating provide only limited, indirect guidance about the range over which the firm's price and potential changes in firm fundamentals. In contrast, the scenario-based valuations are predominantly based on fundamental variables and so this analysis principally explores fundamental risk. Such a fundamental risk perspective is akin to the analyst focusing on future price movements driven by tangible, not intangible, information (e.g., Daniel and Titman, 2006). The scenario valuations convey detailed, contextual and directional

\footnotetext{
${ }^{6}$ For example, the Salomon Smith Barney reports rate stocks as Low, Medium, High, and Speculative. The Citigroup reports rate stocks using five categories: Low Risk, Medium Risk, High Risk, Speculative, and Venture.
} 
information about the source and nature of the joint risk-return tradeoffs associated with a given investment opportunity with a long-term (one year) focus. The approach requires the analyst to provide explicit guidance about the potential range for the firm's long-term value, and allows for a direct examination of whether the assessments of fundamental risk maps into ex post changes in firm fundamentals. $^{7}$

Second, very little is known about how analysts incorporate fundamental risk-return factors into their valuation frameworks. Whereas most forecasted items (earnings, earnings growth, risk ratings) simply reflect the analyst's view about key inputs driving the covered firm's value, the analyst's oneyear-ahead valuation of the firm and related scenario-based valuations give investors definitive information about the firm's valuation and its underlying investment potential (i.e., a joint risk-return assessment). Moreover, although the analysts' target prices are informative, prior research shows that they are systematically optimistic, very inaccurate and have limited long-run investment value (e.g., Brav and Lehavy, 2003; Bradshaw, Brown and Huang, 2013; Bonini, Zanetti, Bianchini and Salvi, 2010). ${ }^{8}$ Thus, although analysts can predict price volatility, as documented in Lui et al. (2007), it is unclear whether analysts accurately assess higher moments of their firms' long-term payoffs and valuation outcomes.

As illustrated by the extant literature, financial analysts typically produce and provide only a single point estimate of their forecasted payoff parameter, whether it is a firm's quarterly or annual earning realization or the target stock price, thus providing an expected value for the firm's earnings or stock price at the end of the forecast horizon. These observed measures of the analysts' expectations are otherwise devoid of explicit quantitative or contextual information about the higher moments of the firm's expected payoff distribution. By focusing on this unique sample of scenario-based valuation investment reports, we can measure cross-sectional differences in the magnitude of uncertainty about the long run valuation outcomes of covered firms as captured by the spread in individual analyst's state-dependent

\footnotetext{
${ }^{7}$ Price volatility and the distribution of long-term valuation outcomes need not be correlated. For example, the long run value of a firm can be known with a high degree of precision, but can display considerable daily excess stock return volatility due to limited liquidity, liquidity shocks, noise trading, or non-synchronous trading activity; alternatively, a firm with significant long-run valuation risk (e.g., lawsuit, competitive threat, M\&A, customer contract expiration) can experience minimal daily volatility if that state-contingent risk never manifests itself or after the risk outcome occurs and/or resolves itself.

${ }^{8}$ The evidence also suggests that target prices are selectively issued (Bradshaw, 2002), sensitive to the valuation model employed (Demirakos, Strong and Walker, 2010; Gleason, Johnson and Li, 2013), and influenced by the analyst's prevailing incentives and overall institutional environment (Bradshaw, Huang and Tan, 2012).
} 
valuation estimates. This ex ante distributional information allows us to document firm-level factors that shape the given analyst's assessment of uncertainty surrounding firm value, and to determine whether these scenario-based valuation estimates convey information about the expected distribution of base case valuation errors (i.e., provide contextual evidence on the perceived risks surrounding the analysts' base case valuation). Given that scenario-based valuations are not commonly included in the vast majority of analysts' publicly released investment reports and that the wide-spread use of scenario-based valuation methods are of a fairly recent origin, the analyst forecasting activities characterized in our research setting have not been analyzed in the extant literature. These reports also provide a unique opportunity to understand, more generally, how financial analysts assess state-contingent risk. ${ }^{9}$

\section{Research design and empirical data on analyst scenario-based forecasts}

\subsection{Research Design: Sample and Data}

Data on analysts' scenario-based valuation estimates are obtained from the complete database of Morgan Stanley analyst reports issued between January 2007 and December 2010 for U.S. publicly listed corporations. ${ }^{10}$ For each firm covered by Morgan Stanley during this period, we identify the first analyst report issued following the start of a given fiscal quarter (denoted quarter $\mathrm{t}$ ). If no report was issued, that firm-quarter observation is not included in the sample. For each firm-quarter containing an analyst report, we then match the firm-quarter report observation with the historical financial information set available to the analyst at the time of the report's issuance. Because the first report of a quarter can occur either before or after the announcement of the preceding quarter's earnings (i.e., quarter t-1's earnings), we

\footnotetext{
${ }^{9}$ Lastly, our paper is indirectly related to a parallel stream of research examining the dispersion in analysts' earnings forecasts. Forecast dispersion is frequently used as an empirical proxy for uncertainty about future earnings outcomes (e.g., Zhang, 2006; Ramnath et al., 2008). However, recent research challenges the risk or uncertainty interpretation of analyst forecast dispersion. Diether, Malloy and Scherbina (2002) show that firms with greater dispersion in analysts' earnings forecasts earn lower future returns, inconsistent with dispersion capturing meaningful differences in uncertainty or firm risk. Additionally, there are conceptual limitations to using the dispersion in analysts' earnings forecasts as a measure of uncertainty. Johnson (2004), for example, points out that because an earnings forecast is just a mean expectation, it is possible for all analysts to agree on the mean of the distribution while each being completely uncertain about the future (e.g., each analyst uses a seasonal random walk forecast model absent any new information); alternatively, each analyst could be extremely confident in their estimates (low uncertainty) while differing wildly from each other because of differential access to information. Our setting has the advantage of capturing a given analyst's assessment of uncertainty and risk about the firm's future payoffs and value at a specific point in time. We view our paper as a compliment to this existing work, and discuss this issue further in section 6.1.

${ }^{10}$ The individual investment reports comprising our sample are publicly available through data sources such as Thomson Financial's Investext database and Bloomberg.
} 
match financial data based on the relative timing of these two events. Specifically, if the report was issued prior to the announcement of quarter t-1's earnings, we match quarter t's analyst report with the firm's quarter t-2 financial information. If the analyst report was issued on or after the earnings release date for the preceding quarter (i.e., quarter t-1), we match the analyst report with the preceding quarter's financial data. This matching approach ensures that our tests are not unduly influenced by a look-ahead bias in financial information. Accounting and stock price data for each firm-quarter observation was gathered through Worldscope and Factset. Firm-quarters with insufficient price and accounting data for our primary tests are eliminated from the sample. These criteria result in a final sample of 6,029 firmquarter observations drawn from 957 unique firms over our sample period.

\subsection{Characteristics of analysts' scenario-based valuation estimates}

\subsubsection{Expected price changes implied by the analyst's scenario-based valuation estimates}

Morgan Stanley requires its analysts to provide three state-contingent value estimates for each firm, labeled "base case," "bull case" and "bear case," when issuing a firm-level investment report. We define the variables $B_{a s e} e_{i, t}, B u l l, t$ and $B e a r_{i, t}$ as the analyst's per share equity valuation estimate under each of these three scenarios, respectively. The analyst's base case valuation reflects performance outcomes and a value realization viewed as being most likely over the forecast horizon. In other words, the base case valuation estimate is the analyst's point expectation of firm value given the firm's anticipated strategic, financial and operational decisions and expected macro-economic conditions; as such, the "base case" forecast is analogous to the traditional stand-alone target price forecast issued by most analysts and used in prior research. In line with that interpretation, we define Base Return $n_{i, t}$ as the anticipated return (excluding dividends) to investing in the firm at the time of the analyst report. Base

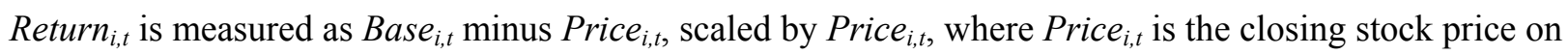
the day before the release of the analyst report. ${ }^{11}$

The analyst's bull case and bear case valuations reflect the analyst's beliefs about firm value under potential alternative economic scenarios. In other words, bull case and bear case forecasts correspond to value estimates under other possible states of the world. These states correspond to potential upside and downside scenarios that would materialize if a certain set of conditions, events or

\footnotetext{
${ }^{11}$ See Appendix 2 for an illustration of the empirical risk-return measures used in our study.
} 
outcomes were to occur, such as shift in the demand for the company's product, the success or failure of a new product launch, a change in the competitive landscape, a change in macro-economic conditions or trends, a shift in the regulatory environment, and a host of other, context-specific, firm, industry or market-level events. We denote the anticipated return (excluding dividends) to investing in the firm at the time of the analyst report under these alternative scenarios as Bull Return $n_{i, t}$ and Bear Return ${ }_{i, t}$, respectively. Each return variable is defined as the difference between a given scenario's target price $\left(\right.$ Bull $_{i, t}$ or Bear $\left._{i, t}\right)$ and Price $_{i, t}$, scaled by Price $_{i, t}{ }^{12}$

\subsubsection{Spread in the analyst's scenario-based valuation estimates}

Together, the analyst's three scenario-based valuation estimates - Bulli,t Base $_{i, t}$ and Bear $_{i, t}-$ convey his/her beliefs about the distribution of the potential valuation outcomes for the firm under different states of the world. The tighter the distribution at the report date, the more certain and less risky the firm's value and payoffs are to the analyst; the wider the distribution, the greater the uncertainty about and risk surrounding firm value and the firm's future payoffs. To measure this notion of uncertainty and risk about the distribution of each firm's future valuation, we create the variable Spread $_{i, t}$, measured as the difference between Bull $_{i, t}$ and Bear ${ }_{\mathrm{i}, t}$, scaled by Base $e_{i, t}$. As defined, Spread ${ }_{i, t}$ captures the relative range in these state-dependent value estimates as a percentage of the base case value estimate and is (by construction) independent of both current prices and the magnitude of anticipated price appreciation. ${ }^{13}$ Spread $_{i, t}$ is analogous to the "cone of uncertainty" that exists in many professional forecasting settings; in this context, Spread $_{i, t}$ conveys information about the potential distribution of future price outcomes under alternative economic states of the world, with the cone centered around the analyst's base case valuation and bounded by his/her bull and bear case valuations.

\footnotetext{
${ }^{12}$ In this context, the anticipated return to the security directly corresponds to the expected appreciation or depreciation in the firm's stock price over the one-year forecast horizon (i.e., capital gain or loss portion of the investors' total return). In the valuation context, the analyst is explicitly forecasting a one-year-ahead stock price outcome, and is not forecasting cum dividend returns to the investor. Our definitions of anticipated returns under a given valuation scenario (Base Return $n_{i, t}$, Bull Return ${ }_{i, t}$, Bear Return $i, t$ ) are consistent with prior research on target price accuracy and target price optimism.

${ }^{13} \mathrm{We}$ also created a second measure of this range, denoted $\operatorname{Spread}_{i, t}$, which equals the difference between $B u l l_{i, t}$ and Bear $_{\mathrm{i}, \mathrm{t}}$, scaled by Price $_{i, t}$. As defined, SpreadP $P_{i, t}$ captures the difference in forecasted returns across the three different valuation scenarios. All results in the study are robust to the use of $\operatorname{Spread}_{i, t}$ in lieu of $\operatorname{Spread}_{i, t}$.
} 


\subsubsection{Ex post accuracy of analyst's base-case valuation}

The ex post accuracy of the analyst's base case valuation estimate is assessed by comparing this valuation estimate against the subsequent price of the firm one year after the issuance of the analyst report. We define the variable Unanticipated Return $_{i, t}$ as the closing equity share price of the firm 365 days after report issuance (adjusted for stock splits) minus the analyst's base case value estimate (i.e., Base $_{i, t}$ ), scaled by the firm's closing price the day before the report's issuance (i.e., Price $e_{i, t}$ ). As defined, Unanticipated Return $_{i, t}$ measures the realized return to the security, net of the anticipated appreciation embedded in the analyst's base case valuation estimate, over the one year period subsequent to the analyst report's release. Unanticipated Return $n_{i, t}$ is frequently referred to either as the analyst's ex post target price error or unexpected return in the extant literature. Absolute valuation errors are measured as the absolute value of Unanticipated Return ${ }_{i, t}$. If analysts accurately assess the degree of state-contingent risk and valuation uncertainty for a given firm, we expect the size of these unsigned deviations from the analyst's base case valuation to be increasing in Spread $_{i, t}$.

\subsection{Descriptive evidence on analysts' scenario-based valuation estimates}

Table 1 presents descriptive statistics on our sample of scenario-based valuation estimates. Focusing on the complete sample of firm-quarter reports (Panel A), we find that the mean (median) report forecasts $15.9 \%(12.2 \%)$ appreciation in the firm's stock price over the analyst's forecast horizon (i.e.,

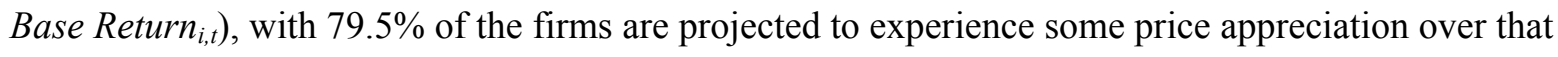
period. This pattern of positive base-case returns is consistent with positive average expected and realized returns for the market over long horizons, with analysts selectively covering firms with strong historical price performance (i.e., positive momentum stocks), strong growth prospects, and high valuation multiples (Stickel, 1995; McNichols and O'Brien, 1997), and with the previously documented optimistic bias in target prices (Brav and Lehavy, 2003; Asquith, Mikhail and Au, 2005).

In terms of the characteristics of the analyst's state-dependent valuation scenarios, the mean (median) forecasted return under bull scenario conditions (i.e., Bull Return $n_{i, \mathrm{t}}$ ) is $53.4 \%(41.8 \%)$, while the mean (median) forecasted return under bear scenarios conditions (i.e., Bear Return $\left.{ }_{i, t}\right)$ is $-27.0 \%(-24.7 \%)$. There is also considerable cross-sectional variation in the magnitude of returns generated under these potential upside and downside scenarios; extreme bull case scenarios generate returns exceeding $240 \%$ 
and extreme bear case scenarios generate losses of $100 \%$. The observed variation in these statecontingent valuation outcomes suggests that analysts' scenario-based valuations reflect highly contextualized analyses and incorporate a diverse set of firm, industry, and macro-economic factors.

These contextual valuations translate into considerable cross-sectional variation in the magnitude of the spread between the analysts' bull case and bear case scenario-based valuation estimates in our sample of firm-quarter reports. The mean (median) Spread $_{i, t}$ is $68.8 \%(61.1 \%)$ of the forecasted base case valuation, consistent with the notion that firm value and underlying payoffs are ultimately statecontingent. Descriptively, firm-quarters in the bottom quartile (decile) have a Spread $_{i, t}$ smaller than $45.2 \%(33.3 \%)$ of the base case valuation, while firm-quarters in the top quartile (decile) have a Spread $_{i, t}$ greater than $82.8 \%(109.0 \%)$ of the base case valuation.

In terms of the ex post accuracy of the analysts' base case valuation estimates, we find that the average (median) security under-performs the return implied by base case expectations by approximately $6.2 \%(8.7 \%)$ over the subsequent year (i.e., unanticipated returns). This average underperformance (i.e., negative valuation error) is consistent with the previously documented optimistic bias in analyst's target prices (e.g., Brav and Lehavy, 2003; Asquith, Mikhail and Au, 2005). ${ }^{14}$ In terms of absolute valuation errors, the average (median) error is $40.4 \%$ (31.1\%) of the analyst's base case valuation, consistent with state-contingent shocks generating large deviations from the analyst's base case valuations. However, there is considerable variation in the absolute magnitude long-run valuation errors. The bottom quartile of absolute valuation errors are concentrated within plus/minus $14 \%$ of the base case valuation (minimal shocks to the base case scenario), while the top quartile experienced errors more than plus/minus 55\% of the base case valuation (large shocks away from the base case scenario). Our primary research objective examines the degree to which the analyst's ex ante assessment of potential state contingent valuation outcomes maps into the ex post distribution of base case valuation errors.

Panel B present mean descriptive statistics on the attributes of these scenario-based forecasts by industry classification. As expected, there exists considerable variation across industries; mean $\operatorname{Spread}_{i, t}$ is higher in the Telecommunications, Energy, Materials, Consumer Discretionary and Financial sectors

\footnotetext{
14 To the extent that the analyst's forecast horizon is actually longer than his/her stated one year horizon, our use of a 365-day post-forecast benchmark will induce an underperformance bias in our sample. The annual horizon will not, however, bias the relative shape of the distribution of ex post realizations conditional upon the ex ante scenario-based forecast characteristics (i.e., wider vs. narrower range of valuation errors, or larger vs. smaller absolute errors).
} 
and systematically lower in the Consumer staples, Utilities and Health Care sectors. Given this systematic variation in the data, we include fixed effects for industry in all of our multivariate analyses.

Panel $\mathrm{C}$ present mean descriptive statistics on the attributes of these scenario-based forecasts by quarter over our sample period. As expected, there is considerable variation over time. Over our sample period, Spread $_{i, t}$ realizations are substantially larger at the start of the financial crisis and economic downturn (Q4 2008, Q1 2009 and Q2 2009), as the shock to credit markets damped down consumer demand and consumption and created significant uncertainty about future economic conditions and firm payoffs. The univariate evidence also documents a shift in both the average Spread $_{i, t}$ contained in these scenario based valuations and in the ex post degree of degree analyst optimism following the financial crisis, suggesting that the financial crisis shock may have altered how analysts' assessed and valued state-continent risk / uncertainty. Given this systematic variation in the data, we include fixed effects for both industry and year-quarters in all of our multivariate analyses. More importantly, additional tests will exploit the financial crisis shock to examine how a systematic, state-contingent shock impacts the analysts' subsequent assessment of fundamental risk and valuation uncertainty.

\section{Empirical analysis of analysts' scenario-based valuation estimates}

This section documents the type of information conveyed by the analyst's ex ante assessment of state-contingent valuation uncertainty about the covered firm. Section 4.1 provides descriptive evidence on the determinants of the spread in analysts' scenario-based valuation estimates. Section 4.2 examines whether these ex ante assessments are related to the absolute magnitude of future base case valuation errors. Section 4.3 provides evidence on whether any relation between Spread $_{i, t}$ and absolute valuation errors is driven by state-contingent shocks to the firms' underlying fundamentals.

\subsection{Determinants of the spread in analysts scenario-based valuation estimates}

\subsubsection{Descriptive firm characteristics}

To assess whether the range of the analyst's state-dependent valuation estimates reflects the inherent riskiness and/or uncertainty surrounding the distribution of the firm's state-contingent payoffs, we measure firm attributes shown to be related to equity risk and analyst's assessments of firm risk (e.g., Beaver, Kettler and Scholes, 1970; Fama and French, 1992; Lui et al., 2007). Drawn from Lui et al. 
(2007), these firm characteristics include: Firm size, beta, idiosyncratic risk, book-to-market, leverage, earnings volatility, losses and negative book values. ${ }^{15}$

Firm size $e_{i, t}$ is defined as the natural logarithm of the firm's market value of equity, measured on the date the analyst report is issued. Beta $a_{i, t}$ captures the firm's exposure to systematic market factors, and is estimated from a market model using the weekly equity return realizations (net of the risk free rate) of the firm and the S\&P 500 index over the preceding 60 weeks. IdioRisk $k_{i, t}$ captures the firm's sensitivity to idiosyncratic risk, and is measured as the natural logarithm of the ratio of one minus the r-squared from a market model estimated using the weekly equity return realizations (net of the risk free rate) of the firm and the S\&P 500 index over the preceding 52 weeks, scaled by the market model r-squared. The firm's book-to-market ratio, $B T M_{i, t}$, captures the firm's growth options and level of financial distress, and is measured as the firm's most recently reported book value, scaled by the firm's market value of equity on the date of the analyst report is issued. The firm's financial leverage, Leverage $e_{i, t}$, is measured as the sum of the firm's short-term and long-term debt, scaled by the book value of common equity. The volatility of the firm's earnings process, EarnVol ${ }_{i, t}$, is measured as the coefficient of variation of the past five year's worth of quarterly net income realizations. The indicator variable $\operatorname{NegEarn}_{i, t}$ is equal to one if the firm is denoted as a loss-making entity, zero otherwise. A firm is identified as a loss-making entity if the sum of the previous four quarters' earnings realizations is negative. Similarly, the indicator variable $N e g B V_{i, t}$ is equal to one if the firm's book value of common equity is negative, zero otherwise.

Because target prices are optimistic, we also include the appreciation embedded in the analyst's base case valuation estimate, Base Return ${ }_{i, t}$, to capture this systematic bias (Brav and Lehavy, 2003). Such an optimistic bias can influence the analysts' assessment of state-contingent valuation outcomes in two ways. If optimism causes an analyst to report a range of state contingent valuations that do not fully incorporate the potential downside risk to the firm, we would expect a negative association between

\footnotetext{
${ }^{15}$ There also exists a parallel stream of research that uses historical financial accounting data to assess or predict the riskiness of a firm's equity. Beaver, Ketttler and Scholes (1970) examines the financial determinants of market and accounting betas, and examines whether historical and forecasted accounting betas can predict future return realizations. Rosenberg and Marathe (1975) find that accounting variables improve the ability to forecast systematic risk over using market data alone. Penman (2010) briefly reviews this past literature and discusses how accounting information can be better used for risk assessment, forecasting, and valuation. We use the results from this stream of literature to identify additional firm-specific factors associated with fundamental risk. All multivariate results in the paper are robust to the inclusion of historical return on equity $\left(\mathrm{ROE}_{\mathrm{i}, t}\right)$, sales growth $\left(\right.$ Growth $\left._{i, t}\right)$, change in return on equity $\left(\triangle R O E_{i, t}\right)$ in our full model specifications. These variables are omitted in our tabulated analyses to enhance comparability with the results presented in Lui, Markov, and Tamayo (2007).
} 
Spread $_{i, t}$ and Base Return $i, t$. Similarly, if optimism is either driven by or correlated with over-confidence, we would expect more optimistic analysts to produce a narrower distribution of scenario-based valuations around their base case valuation than warranted. Such artificial precision will also result in a negative association between Spread $_{i, t}$ and Base Return $i, t$.

Table 2, panel A presents descriptive evidence on our sample of firm-quarters observations. Consistent with prior research, the covered firms tend to be large (mean Firm Size $e_{i, t}$ of $\$ 17.6$ billion) and have significant growth prospects (mean $B T M_{i, t}$ of 0.561 ). However, there exists considerable variation in these economic attributes across the sample; for example, twenty-five percent of the firms have market capitalizations less than $\$ 2.1$ billion and $9.1 \%$ of the firms experience losses over the preceding four quarters. ${ }^{16}$

Panel B presents Spearman correlations between these firm characteristics and the attributes of the analyst's scenario based forecasts. Several interesting relations are observed. First, consistent with prior work on the fundamental determinants of risk, firm characteristics expected to increase equity risk are positively associated with the spread in analysts' scenario-based valuation estimates. Specifically, Spread $_{i, t}$ is positively correlated with the firm's exposure to market risk $\left(\operatorname{Beta}_{i, t}\right)$, lack of growth options / financial distress risk $\left(B T M_{i, t}\right)$, earnings volatility $\left(\operatorname{EarnVol}_{i, t}\right)$, and the presence of loss making activities $\left(\operatorname{NegEarn}_{i, t}\right)$ and negatively correlated with Firm Size ${ }_{i, t}{ }^{17}$

\subsubsection{Evidence on the determinants of spread in scenario-based valuation estimates}

The descriptive evidence in Table 2 shows that $\operatorname{Spread}_{i, t}$ is correlated with attributes typically associated with greater firm risk, yet because many of these firm characteristics are correlated, it is difficult to identify which characteristics directly influence the analyst's assessment of firm risk. Moreover, because many characteristics are driven by industry affiliation, these correlations do not shed light on whether analysts are incorporating firm-specific attributes into these risk assessments, or simply forecasting risk-return on the basis of industry affiliation alone.

\footnotetext{
${ }^{16}$ We also present descriptive statistics on the firm's historical return on equity realizations $\left(R O E_{i, t}\right)$, as well as three fundamental performance variables used in our ex post prediction tests - historical sales growth $\left(G r o w t h_{i, t}\right)$, change in return on equity $\left(\triangle R O E_{i, t}\right)$, and change in operating profit margin $\left(\Delta \operatorname{Margin}_{i, t}\right)$. All variables are defined in Appendix 1.

${ }^{17}$ The Spearman correlation between Spread $_{i, t}$ and Base Return $i, t$ is 0.097 . The correlation between these forecast attributes are not tabulated for parsimony.
} 
To identify firm-specific factors influencing the analyst's assessment of future risk and valuation uncertainty, we estimate various specifications of the following cross-sectional model:

$$
\begin{aligned}
& \text { Spread }_{i, t}=\alpha+\text { Industry }^{\text {Quarter }}+\beta_{1} \text { Firm Size }_{i, t-1}+\beta_{2} \text { Beta }_{i, t-1}+\beta_{3} \text { IdioRisk }_{i, t-1}+\beta_{4} B T M_{i, t-1}+\beta_{5} \text { BTM }_{i, t-1} * \text { NegBV }_{i, t-1} \\
& +\beta_{6} \text { Leverage }_{i, t-1}+\beta_{7} \text { Leverage }^{*} N e g B V_{i, t-1}+\beta_{8} \text { EarnVol }_{i, t-1}+\beta_{9} \operatorname{NegEarn}_{i, t-1} \\
& +\beta_{10} N e g B V_{i, t-1}+\beta_{11} \text { Base Return }_{i, t-1}+\varepsilon_{\mathrm{i}, \mathrm{t}}
\end{aligned}
$$

In these estimations, Industry is an array of nine industry indicator variables based on the firm's GICS sector classification, and Quarter is an array of fifteen quarter-specific indicator variables. These indicator variables are designed to capture the influence of industry affiliation and time period fixed effects on the analysts' scenario-based valuation estimates. All estimations utilized pooled, crosssectional data; standard errors are clustered at the firm level. All variables are defined in Appendix 1.

Table 3 presents select coefficients from these estimations of equation (1). The first specification only includes empirical proxies for the firm's exposure to systematic and idiosyncratic risk factors (i.e, Beta $_{i, t}$ and IdioRisk $k_{i, t}$ ). The second estimation includes the three Fama and French (1992) factors (i.e., Beta $_{i, t}$, Firm Size $_{i, t}$, and $\left.B T M_{i, t}\right)$ in addition to the firm's exposure to idiosyncratic risk. The third model is drawn from the specifications in Lui et al. (2007), incrementally including the firm's leverage ratio (Leverage $\left.{ }_{i, t}\right)$, profitability variable $\left(\operatorname{NegEarn}_{i, t}\right)$ and quarterly earnings volatility $\left(\operatorname{EarnVol}_{i, t}\right)$ into the earlier estimations. The last specification includes the inherent degree of optimism / expected return performance embedded in the analyst's base case valuation (Base Return $\left._{i, t}\right)$.

These estimations document that Spread $_{i, t}$ is significantly associated with firm-level characteristics that capture the riskiness of the firm's operations and equity. First, before and after controlling for other firm attributes, Spread $_{i, t}$ is increasing in the firm's exposure to both systematic and idiosyncratic risk. Second, Spread $_{i, t}$ is positively associated with beta and book-to-market ratios and negatively associated with firm size, consistent with the risk-based interpretation for Fama and French's (1992) three-factor model. Third, Spread ${ }_{i, t}$ is incrementally larger for highly levered firms and loss making entities, suggesting that analysts consider firm-specific, fundamental factors beyond those outlined in traditional asset pricing models (e.g., CAPM and Fama-French three factor model) when assessing the distribution of potential state-contingent payoffs to the firm. Fourth, after controlling for firm fundamentals, Spread $_{i, t}$ is decreasing in the degree of optimism embedded in the analyst's base case valuation. Finally, these firm-specific relations are incremental to controls for industry affiliation and 
time-period fixed effects, again suggestive that analysts differentiate risk at the firm level, and jointly utilize firm, industry and market-level (i.e., period specific) information when making these scenariobased forecasts.

These estimations document that analysts' scenario based valuation estimates are systematically associated with firm-specific factors expected to be correlated with fundamental risks and uncertainty surrounding the firm's long run payoffs. The next two sections examine whether these scenario-based valuation forecasts can predict the distribution of the firm's future long-term payoffs.

\subsection{Analysts' scenario-based valuations and the distribution of one-year-ahead valuation errors}

The basic premise behind our prediction tests is that the relative spread in the analysts' scenariobased valuation estimates (narrow vs. wide) should be associated with the absolute magnitude of ex post base case valuation errors if analysts are correctly assessing state-contingent risk. Specifically, firms with less value uncertainty (smaller Spread $_{i, t}$ ) will have a tighter distribution of ex post base case valuation

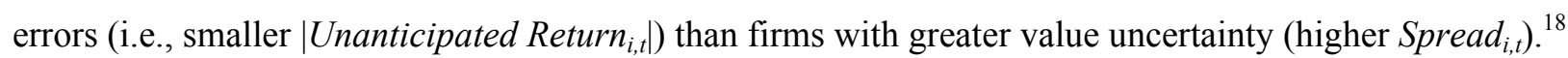

\subsubsection{Descriptive evidence: Distribution of future return realizations conditional upon Spread ${ }_{i, t}$.}

Table 4 presents descriptive, portfolio-level evidence on the distribution of one-year-ahead forecasted, realized, and unanticipated returns, conditional upon the analysts' assessment of Spreadi,t. To form these portfolios, Spread $_{i, t}$ observations are ranked and sorted into quintiles each quarter based on that quarter's distribution of $\operatorname{Spread}_{i, t}$ realizations. This procedure results in five Spread ${ }_{i, t}$ portfolios, with the first (fifth) quintile containing the firm-quarter observations with the smallest (largest) Spread ${ }_{i, t}$ realizations in a given quarter. We calculate and document four return metrics for each firm-quarter

\footnotetext{
${ }^{18}$ To illustrate, consider a firm for which there is no uncertainty about the future value and analysts are rational. In that setting, the analyst's three valuation scenarios would yield the same valuation (i.e., $B u l l_{i, t}=$ Base $_{i, t}=$ Bear $_{i, t}$ ) and same anticipated price change $\left(\right.$ Bull Return $_{i, t}=$ Base Return $_{i, t}=$ Bear Return $\left._{i, t}\right)$. Barring any unexpected economic events, realized price will ultimately equal the original value estimate, and as a result, the observed unexpected change in price (Unanticipated Return ${ }_{i, t}$ ) will be zero. As uncertainty increases, the difference between the analyst's bull case and bear case valuation estimates will widen. Assuming no systematic biases in the analysts' base case valuation, realized prices will still be centered at the base case valuation, but ex post price realizations will form a distribution around this central tendency as uncertainty about future firm performance and value resolves itself. For a portfolio of firms with only minimal uncertainty, the distribution of ex post base case valuation errors, Unanticipated Return ${ }_{i, t}$, will be narrow; for firms with more uncertainty, the ex post distribution will be wider. The important inference is that greater ex ante uncertainty about payoffs, as reflected in Spread $_{i, t}$, should be associated with a broader distribution of base case valuation errors (i.e., greater variance in Unanticipated Returns $s_{i, t}$ ) if analysts correctly forecast differences in scenario-based risk across firms.
} 
observation in a given portfolio: Base return $n_{i, t}$, Raw return ${ }_{i, t}$, Unanticipated Return $_{i, t}$ and the absolute value of Unanticipated Return $_{i, t}$.

This portfolio-level analysis yields several key results. First, both the analysts' average anticipated price change (Base Return ${ }_{i, t}$ ) and the standard deviation of these outcomes are increasing in Spread $_{i, t}$. At this aggregate portfolio level, firms perceived by the analyst community as having greater outcome-based risk are both forecasted to earn average higher returns and to experience a greater variance in long-term outcomes than firms assessed as possessing less fundamental risk.

Second, future raw returns are increasing in $\operatorname{Spread}_{i, t}$ (panel B). This positive relation is consistent with riskier firms earning a risk premium over less risky firms. Additionally, the standard deviation of these long-run raw return realizations is increasing across Spread $_{i, t}$ quintiles, consistent with greater ex ante risk assessments translating into a great dispersion in ex post price outcomes. This increase in the range of these long-term outcomes is also embedded in the broader distributional data, as evidence by larger inter-quartile ranges (tabulated) and greater differences between $10^{\text {th }}$ and $90^{\text {th }}$ percentile and the $5^{\text {th }}$ and $95^{\text {th }}$ percentile realizations for the firm-quarters in the larger Spread $d_{i, t}$ portfolios (not tabulated for parsimony).

Third, mean Unanticipated Return $i, t$ is unrelated to Spread $_{i, t}$, consistent with observed differences in forecasted price changes principally reflecting differences in required risk premia (Panel C). However, similar to raw returns, both the standard deviation and the inter-quartile range of Unanticipated Return $n_{i, t}$ realizations are strictly increasing across Spread $_{i, t}$ portfolios. Thus, after adjusting for the analyst's "expected" price movements, unanticipated price innovations are centered around the same central tendency regardless of the firm's Spread $_{i, t}$, and all differences in Unanticipated Return realizations across portfolios are confined to the higher moments of the distribution.

Fourth, differences in long-run outcome volatility become clear when we examine absolute unexpected price changes conditional upon ex ante risk assessment (panel D); mean and median realizations of $\mid$ Unanticipated Return $_{i, t} \mid$ are strictly increasing across Spread ${ }_{i, t}$ portfolios. Similarly, the width of the distribution of $\mid$ Unanticipated Return $_{i, t} \mid$, as captured by the standard deviation and interquartile range, is generally increasing across these quintiles. This absolute deviation between realized and anticipated returns is an important metric, as it will allow us to examine cross-sectional variation in the magnitude of ex post base case valuation errors at the firm-quarter level. 


\subsubsection{Multivariate analysis: Spread ${ }_{i, t}$ and the absolute magnitude of base case valuation errors.}

To further explore these relations, we estimate various specifications of the following crosssectional model:

$$
\begin{aligned}
& \mid \text { Unanticipated Return }_{i, t} \mid=\alpha+\text { Industry }+ \text { Quarter }+\beta_{1} \text { Spread }_{i, t}+\beta_{2} \text { Base Return }_{i, t-1}+\beta_{3} \text { Firm Size }_{i, t-1}+\beta_{4} \text { Beta }_{i, t-1} \\
& +\beta_{5} \text { IdioRisk }_{i, t-1}+\beta_{6} \text { BTM }_{i, t-1}+\beta_{7} \text { BTM }_{i, t-1} * \operatorname{NegBV}_{i, t-1}+\beta_{8} \text { Leverage }_{i, t-1}+\beta_{9} \text { Leverage }_{i, t-1} * \operatorname{NegBV}_{i, t-1} \\
& +\beta_{10} \text { EarnVol }_{i, t-1}+\beta_{11} \operatorname{NegEarn}_{i, t-1}+\beta_{12} \operatorname{NegBV}_{i, t-1}+\varepsilon_{\mathrm{i}, \mathrm{t}}
\end{aligned}
$$

In these estimations, our dependent variable is the absolute unexpected price change over the one-year

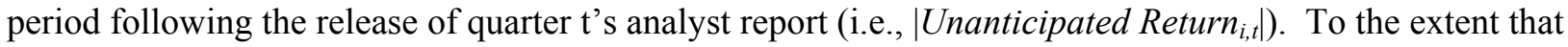
firms with greater ex ante risk experience a wider distribution of long term valuation outcomes, we expect

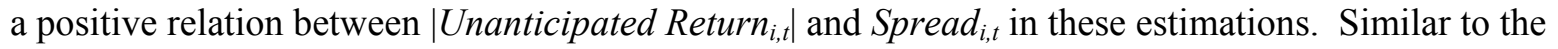
determinants analysis, Industry is an array of nine industry indicator variables based on the firm's GICS sector classification, and Quarter is an array of fifteen quarter-specific indicator variables. All other variables are defined in Appendix 1. These estimations utilized pooled, cross-sectional data; standard errors are clustered at the firm level. ${ }^{19}$

Table 5 presents select coefficients from these estimations of equation (2). The first set of columns present coefficients from estimations using the full sample of firm-quarter reports. The remaining two columns present coefficients after excluding reports issued in advance of the financial crisis (fourth quarter of 2007 through third quarter of 2008) and after excluding reports issued during the height of the financial crisis (fourth quarter 2008 through second quarter of 2009). ${ }^{20}$ Regardless of the sample examined, these estimations reveal that analysts' assessments of risk, as captured by Spread $d_{i, t}$, have significant incremental explanatory power for the absolute magnitude of future long-run unexpected price changes. ${ }^{21}$ The positive coefficients on Spread $_{i, t}$ document that the variance of unexpected price changes is increasing in the ex ante risk surrounding the analyst's base case forecast; economically, the estimated coefficients imply that a ten percent increase in the relative spread between bull and base case

\footnotetext{
${ }^{19}$ Documented relations and the statistical significance of our key results are robust to the use of a quarterly FamaMcBeth estimation methodology, where standard errors are estimated using the empirically-derived distribution of quarterly coefficient estimations.

${ }^{20}$ These results are also robust to the exclusion of all seven quarters impacted by the financial crisis.

${ }^{21}$ These results are also robust to logarithmically transforming the dependent variable to control for the impact of heteroskedasticity in the data.
} 
scenario-based valuation estimates (as a fraction of the base case value) corresponds to an approximate one percent to two-and-a-half percent increase in the average absolute unexpected return movements over the one year forecast horizon. The documentation of this second moment effect with respect to distribution of future long-term return realizations is precisely the dimension of risk that the scenariobased valuation process is designed to identify. This evidence is especially interesting given that the analyst's base case valuation appears inherently biased. The joint evidence suggests that analysts systematically identify the plausible range of valuation outcomes given the risks and rewards facing the firm, but bias their target price within that band of uncertainty in response to prevailing incentives and/or behavioral biases.

Taken together, the evidence in the preceding two sections suggests that analysts' scenario-based valuation forecasts contain information about the state-contingent risk factors that can affect long-run firm value. This underlying risk manifests itself in terms of the absolute magnitude of base case valuation errors. The next section examines whether the predictive ability is driven by anticipated shocks to the firms' fundamentals.

\subsection{Relation between analysts' scenario-based valuations and future changes in firm fundamentals.}

The predictive evidence presented so far focuses on unanticipated deviations between the analysts base case valuation estimates and realized prices one year after the report's release (i.e., base case valuation errors). If these analyst reports are truly conveying information about state-contingent fundamental risk, the distribution of ex post base case valuation errors should be driven by observable state contingent shocks to the firm's fundamentals. In other words, the predictability of scenario-based valuation outcomes should be arising from the analysts' ability to identify potential economic events that shock the firm's operating performance. ${ }^{22}$

We provide evidence on this mapping by examining whether Spread $_{i, t}$ is associated with (i.e., predictive of) the magnitude of future innovations in firm fundamentals. For each firm-quarter observation, we calculate one-year-ahead, seasonally-adjusted changes in the covered firm's return on

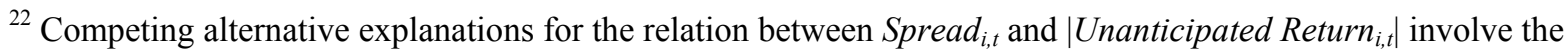
analyst forecasting investor sentiment, assessing the likelihood of long-run pricing errors reversing / continuing, and/or forecasting long-term return volatility independent of firm fundamentals. These alternative explanation would posit no relation between Spread $_{i, t}$ and absolute changes in the firm's future fundamentals.
} 
equity, operating margins, and revenue. We expect the absolute value of these one-year-ahead innovations to be increasing across Spread $_{i, t}$ portfolios. Table 6 presents this evidence.

We find that firm-quarters associated with larger $\operatorname{Spread}_{i, t}$ are associated with large absolute changes to the firms fundamentals in the year following the release of the analyst report (Panel A). This positive relation is consistent with firms being assessed as inherently riskier subsequently experiencing larger shocks - both positive and negative - to their operations and payoffs over the subsequent four quarters. This positive relation between $\operatorname{Spread}_{i, t}$ and the absolute magnitude of these shocks to fundamentals exists for all three metrics of firm performance ( $\triangle R O E, \triangle M a r g i n s$, and Growth). This positive relation is robust to controls for the most recent historical quarterly innovation in each of these absolute realizations, plus industry and quarter fixed effects (panel B). All results are also robust to eliminating firm-quarter observations impacted by the financial crisis. Together, this evidence confirms that the positive relation between Spread $_{i, t}$ and $\mid$ Unanticipated Return $_{i, t} \mid$ is driven by analysts' ability to assess the distribution of firm fundamental payoffs in other plausible states of the world.

\section{Impact of the macro-economic shock on the analysts' assessment of state-contingent risk}

The preceding analyses document that analysts are capable of assessing and conveying information about state-contingent valuation risk and uncertainty, as captured by the distribution of oneyear-ahead base case valuation errors (i.e. target price errors) and changes in firm's fundamentals. These results are robust to the inclusion and exclusion of analyst, price and financial data impacted by the financial crisis. In the preceding analyses, we are careful to perform robustness tests that excluded the financial crisis data due to concerns that the macro-economic event could potentially confound our inferences about analysts' ability to assess fundamental risk. In this section, we exploit the shock to the US economy to provide additional insights into how analysts' assess fundamental risk and incorporate uncertainty into their scenario-based valuations. Because the financial crisis was a manifestation of statecontingent risk, and generated significant uncertainty about firm performance, the event likely required analysts to explore more deeply the fundamental drivers of firm performance and risk. To the extent that the event revealed new information to analysts, or changed their forecasting behavior, we would expect Spread $_{i, t}$ to be more informative about the firm's risk-return attributes following the event. Our first set of analyses examines whether the financial crisis impacted the ex ante spread in analyst's state-contingent 
valuations. Our second set of analyses examines whether the financial crisis impacted the predictive ability / information content of the analysts' assessment of state-contingent risk.

\subsection{Impact of macro-economic shock on the analysts' assessment of valuation uncertainty}

We expect the financial crisis to influence Spread $_{i, t}$ though several channels. First, we expect Spread $_{i, t}$ to exhibit inter-temporal variation conditional upon the timing of the analyst report (i.e., before, during or after the financial crisis). Essentially, reports issued at the height of the crisis should display more valuation uncertainty than reports issued before or after the crisis. Second, to the extent that the crisis changed the average analysts' awareness of or sensitivity to macro factors in their valuation process (e.g., recency effect), we would expect to observe larger spreads after the financial crisis than before the crisis. Lastly, any shift in risk assessment should be systematically related to firms' fundamental exposure to macro-economic or state-contingent risks; thus, we expect to observe a shift in the sensitivity of the analysts' assessment of state-contingent valuation outcomes to various firm-specific risk characteristics following the financial crisis.

Consistent with this intuition, the descriptive evidence in Table 1, Panel C documents that analysts expanded the range of potential valuation outcomes of covered firms in response to the uncertainty created by the macro-economic shock. The effect is strongest in the three quarters at the height of the crisis, with analysts subsequently lowering their assessment after the immediate shock subsides. However, consistent with the financial crisis raising both fundamental risk and analyst awareness after the event occurred, investment reports issued subsequent to the height of the financial crisis continue to contain larger valuation spreads relative to reports issued before the crisis started. This inter-temporal pattern of rising and falling, but not fully reverting, scenario-based valuation spreads is consistent with analysts' dynamically and systematically revising their state-contingent valuation models and assessments in response to macro-economic events. ${ }^{23}$

To examine whether the sensitivity of analysts' Spread $_{i, t}$ assessments to risk factors and optimism shifted after the start of the financial crisis, we estimate the following cross-sectional model using a subsample of reports issued before and after the start of the financial crisis, respectively:

$$
\text { Spread }_{i, t}=\alpha+\text { Industry }+\beta_{1} \text { Firm Size }_{i, t-1}+\beta_{2} \text { Beta }_{i, t-1}+\beta_{3} \text { IdioRisk }_{i, t-1}+\beta_{4} \text { BTM }_{i, t-1}+\beta_{5} B T M_{i, t-1} * N e g B V_{i, t-1}
$$

\footnotetext{
${ }^{23}$ These inter-temporal effects are statistically significant, and robust to a multivariate specification that controls for variation in firm-specific characteristics over these periods. Multivariate models are not tabulated for parsimony.
} 


$$
\begin{aligned}
& +\beta_{6} \text { Leverage }_{i, t-1}+\beta_{7} \text { Leverage }^{*} N e g B V_{i, t-1}+\beta_{8} \text { EarnVol }_{i, t-1}+\beta_{9} \operatorname{NegEarn}_{i, t-1}+\beta_{10} \operatorname{NegBV}_{i, t-1}
\end{aligned}
$$

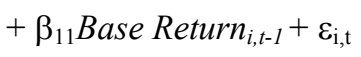

An investment report is classified as Pre-Financial Crisis (Post-Financial Crisis) if it was issued before (after) the start of the financial crisis, defined as before the fourth quarter (after the third quarter) of 2008. All estimations utilized pooled, cross-sectional data and standard errors are clustered at the firm level; tests of differences in coefficients between these time periods are based upon a spline regression specification of this model.

Coefficients from the estimations of equation (3) are presented in Table 7. These estimations, and tests of differences in coefficients, reveal that following the crisis analysts placed an incrementally greater weight on the firm's systematic risk factor (i.e., $B e t a_{i, t}$ ), insolvency risk (i.e., negative book value

of equity) and extreme leverage (Leverage ${ }_{i, t}{ }^{*}$ Negative $B V_{i, t}$ ). Such a response is intuitive given the nature and form of the financial crisis - a systematic risk event with a material credit risk / credit market component. Interestingly, the financial crisis dramatically lowered the role that the analysts' optimistic target price bias had on their assessment of state contingent valuation risk. Following the crisis, Spread $_{i, t}$ is no longer related to the analyst's optimistic bias, suggesting that the macro-economic event attenuated behavioral biases (or incentives) which adversely affected their ability to assess and/or communicate information about fundamental risk.

\subsection{Impact of macro-economic shock on the predictive ability of analysts' assessment of state-contingent} valuation uncertainty

The natural question is whether the observed shift in the analysts' state-contingent risk assessments following the financial crisis improved the predictability of their scenario-based valuations. The descriptive evidence in Table 1, panel C, suggests that financial crisis impacted the accuracy of the analysts' base case valuations. Consistent with the macro-economic shock significantly creating significant uncertainty about future payoffs, we observe that ex post absolute valuation errors were larger for reports issued during the height of the financial crisis (Q4 of 2008 through Q2 of 2009). More importantly, however, we observe that absolute valuation errors associated with reports issued after the height of the financial crisis are smaller than valuation errors associated with reports issued before the 
crisis, suggesting that the crisis made analysts aware of and sharpened their ability to assess state contingent risk and impound that information into their base case valuations (and potentially lowered uncertainty about the base case). Similar to their ex ante assessments, such an inter-temporal pattern in outcomes is consistent with analysts' dynamically and systematically revising their state-contingent valuation models and assessment in response to macro-economic events. ${ }^{24}$

To investigate this issue more directly, we examine whether the relations between ex post valuation errors, analysts' Spread $_{i, t}$ assessments, risk factors, and optimism changed after the start of the financial crisis. To the extent that assessments made after the start of the financial crisis better reflect state-contingent risk, we expected to observe a stronger relation between $\mid$ Unanticipated Return $_{i, t} \mid$ and Spread $_{i, t}$, and weaker relations between | Unanticipated Return $_{i, t}$, firm-specific risk attributes and analyst optimism, after the start of the crisis.

To test these arguments, we estimate the following cross-sectional model using a subsample of reports issued before and after the start of the financial crisis, respectively:

$$
\begin{aligned}
& \mid \text { Unanticipated Return }_{i, t} \mid=\alpha+\text { Industry }+\beta_{1} \text { Spread }_{i, t-1}+\beta_{2} \text { Base Return }_{i, t-1}+\beta_{3} \text { Firm Size }_{i, t-1}+\beta_{4} \text { Beta }_{i, t-1} \\
& +\beta_{5} \text { IdioRisk }_{i, t-1}+\beta_{6} B T M_{i, t-1}+\beta_{7} \text { BTM }_{i, t-1} * N e g B V_{i, t-1}+\beta_{8} \text { Leverage }_{i, t-1}+\beta_{9} \text { Leverage }_{i, t-1} * N e g B V_{i, t-1} \\
& +\beta_{10} \operatorname{EarnVol}_{i,-1}+\beta_{11} \operatorname{NegEarn}_{i, t-1}+\beta_{12} N e g B V_{i, t-1}+\varepsilon_{i, t}
\end{aligned}
$$

Similar to the preceding analysis, an investment report is classified as Pre-Financial Crisis (Post Financial Crisis) if it was issued before (after) the start of the financial crisis, defined as before the fourth quarter (after the third quarter) of 2008. All estimations utilized pooled, cross-sectional data and standard errors are clustered at the firm level; tests of differences in coefficients between these time periods are based upon a spline regression specification of this model.

Coefficients from the estimations of equation (4) are presented in Table 8. These estimations, and tests of differences in coefficients, reveal that after the start of the financial crisis, the absolute value of valuation errors display an incrementally greater association with the analysts ex ante assessment of risk (i.e., Spread $_{i, t}$ ). Moreover, because the analyst placed greater weight on the firm's systematic risk factor (i.e., Beta) after the financial crisis when forming their ex ante assessment, we observe that

\footnotetext{
${ }^{24}$ Similar to the preceding analyses, these inter-temporal effects are statistically significant, and robust to a multivariate specification that controls for variation in firm-specific characteristics over these periods. Multivariate models are not tabulated for parsimony.
} 
$\mid$ Unanticipated Return $_{i, t} \mid$ is no longer associated with the firm's systematic risk following the crisis. This substitution, where absolute valuation errors are now captured by the analysts' Spread $_{i, t}$ assessment and not a firm fundamental (i.e., Beta), is precisely the pattern that should emerge if analysts are more efficiently incorporating state-contingent macro risk into their scenario-based valuations following the crisis. Additionally, following the crisis, the relation between analysts' optimistic bias and |Unanticipated

Return $_{i, t}$ is significantly weaker, again suggesting that the macro-economic event attenuated behavioral biases (or incentives) which adversely affected their ability to assess and/or communicate information about fundamental risk.

Together, Tables 7 and 8 provide some of the first evidence in the literature on how analyst valuations and risk assessment activities are impacted by and dynamically evolve in response to large macro-economic shocks. This evidence also confirms that Spread $_{i, t}$ is capturing a dimension of risk directly related to the firm's long-run payoffs. Whereas the prior literature (and early institutional risk assessment activities) were focused on average daily excess stock return volatility, this long-run payoff aspect of our analysis provides a unique insight on the valuation activities of analysts and provides a novel contribution to the extant literature.

\section{Additional analyses and robustness tests}

\subsection{Analyst forecast dispersion versus scenario-based valuation estimates}

A commonly used empirical measure to characterize analysts' uncertainty about the firm's future payoffs and firm value is analyst forecast dispersion. Both theoretically and practically, analyst forecast dispersion is fundamentally different than $\operatorname{Spread}_{i, t}$. By construction, forecast dispersion captures disagreement between analysts about a particular firm-level performance construct (e.g., one-year-ahead or two-year-ahead earnings). Such disagreement can arise for many reasons, including uncertainty about the firm's most likely future outcomes, but can also arise as a result of differential access to information, difference in the weighting of public vs. private information, the use of different forecasting models, differences in analyst ability, etc. (see Johnson (2004) for a further discussion). Because of these factors, observed forecast dispersion can be attributable to both heterogeneity in analyst attributes and uncertainty about firm fundamentals. Additionally, as an empirical measure, forecast dispersion only provides information about the attributes of the first moment of expected performance under the analysts' base 
case scenario, with each individual analyst providing no explicit information about performance under alternative states of the world (except to the extent that such beliefs about alternative states drive variation in their base case forecasts). In contrast, the use of analysts' scenario-based valuation estimates to make inferences about fundamental risk and to assess beliefs about the ex ante distribution of payoffs under alternative valuation scenarios avoids many of these confounding factors. The information contained in each individual analyst's scenario-based valuations (i.e., Spread $_{i, t}$ ) reflects his/her assessment of the higher moments of the firm's of potential valuation outcomes at a specific point in time; this attribute allows researchers and investors to observe and measure higher moment beliefs while holding analystlevel attributes constant at the firm-quarter level.

Table 9 presents evidence on the relation between future outcomes and analysts' scenario-based valuation attributes after controlling for the contemporaneous level of analyst forecast dispersion. In these tests, Dispersion_FY1 and Dispersion_FY2 are measured as the standard deviation of one-yearahead and two-year-ahead earnings forecasts, scaled by the consensus FY1 and FY2 earnings forecast, respectively, during the month the analyst report is released. All data on analyst forecasts is gathered from the $\mathrm{I} / \mathrm{B} / \mathrm{E} / \mathrm{S}$ consensus database. We require the firm to have at least three earnings forecasts to compute a given forecast dispersion statistic. These analyses reveal several interesting findings. First, Spread $_{i, t}$ and our two measures of forecast dispersion are significantly positively correlated (Spearman correlations of 0.480 and 0.545 , respectively; not tabulated for parsimony); this positive relation is unsurprising given that forecast dispersion can capture uncertainty about future long-term payoffs with error. Second, all inferences about the relations between both Spread $_{i, t}$ and the distribution of future outcomes are robust to the inclusion of analyst forecast dispersion in the models. Third, unlike Spreadi,t $_{i,}$ neither measures of analyst forecast dispersion has an incremental association between the distribution of long-run outcomes after controlling for basic firm characteristics. Together, the evidence both casts doubt on the use of analyst forecast dispersion as an empirical proxy for uncertainty about fundamental value and validates our inferences about the type of information being conveyed by the analysts' statecontingent value estimates.

\subsection{State contingent risk versus short-term volatility}

Existing research examining financial analysts' ability to assess risk has exclusively focused on categorical risk ratings. As discussed earlier, the type of risk and uncertainty being captured by an 
analyst's set of scenario-based valuations is inherently different than the type of risk that manifests itself as daily stock price volatility or the sensitivity of daily returns to risk factors. To provide clarity on this point, we gathered data on "volatility flags" issued by Morgan Stanley analysts and examine the extent to which the analysts' assessments of state-contingent risk reveal information incremental to the issuance of a volatility flag.

Prior to the implementation of the Risk-Reward framework, Morgan Stanley analysts were required to identify risky securities through the issuance of a "volatility flag" in their investment reports. ${ }^{25}$ This indicator, proprietary to Morgan Stanley, is similar to the categorical risk measures issued by other brokerage houses and examined in the Lui et al. (2007; 2012) studies. Interestingly, Morgan Stanley viewed the introduction of the Risk-Reward presentation as the replacement of the volatility flags and phased out the use of this volatility indicator after the introduction of the Risk-Reward framework. More importantly, there exists a short historical window - Q1 2007 through Q3 2008 - over which reporting analysts were jointly issuing scenario-based valuations and assigning a volatility flag to the covered firm. We exploit this dual reporting regime to examine the incremental information contained in the analysts' scenario-based valuations vis-à-vis their categorical measure of firm risk.

The intersection of Morgan Stanley's scenario-based valuation data and their and volatility flag data yields 2,016 firm-quarter analysts reports for 697 unique firms. For this subsample of analyst reports, we examine the association between one-year ahead absolute base case valuation errors and the analysts' two risk assessment measures, Spread $_{i, t}$ and Volatility Flag ${ }_{i, t}$, through various estimations of the following cross-sectional model:

$$
\begin{aligned}
& \mid \text { Unanticipated Return }_{i, t} \mid=\alpha+\text { Industry }+ \text { Quarter }+\beta_{1} \text { Spread }_{i, t-1}+\beta_{2} \text { Volatility Flag }_{i, t}+\beta_{3} \text { Base Return }_{i, t-1} \\
& +\beta_{4} \text { Firm Size }_{i, t-1}+\beta_{5} \text { Beta }_{i, t-1}+\beta_{6} \text { IdioRisk }_{i, t-1}+\beta_{7} \text { BTM }_{i, t-1}+\beta_{8} \text { BTM }_{i, t-1} * \text { NegBV }_{i, t-1}+\beta_{9} \text { Leverage }_{i, t-1} \\
& +\beta_{10} \text { Leverage }_{i, t-1} * N e g B V_{i, t-1}+\beta_{11} \text { EarnVol }_{i, t-1}+\beta_{12} \operatorname{NegEarn}_{i, t-1}+\beta_{13} N e g B V_{i, t-1}+\varepsilon_{i, t}
\end{aligned}
$$

\footnotetext{
${ }^{25}$ In particular, the volatility flag was assigned if the analyst estimated that the stock has more than a $25 \%$ change of a price move (up or down) of more than $25 \%$ in a month, based on a quantitative assessment of historical data, or if she thought the stock was likely to become materially more volatile over the next 1-12 months compared with the past three years. In addition, stocks with less than one year of trading were automatically rated as more volatile (unless otherwise noted).
} 
In this model, Volatility Flag $_{i, t}$ is an indicator variable equal to one if the analyst had an outstanding "volatility flag" assessment in place at the time a given quarterly investment report was issued, zero otherwise.

Select coefficients from these estimations are presented in Table 10. The first set of columns present coefficients from estimations using the full sample of available data. The second set of column focuses on observations that are not impacted by the financial crisis (i.e., reports issued before Q4 2007). This smaller, earlier sample of reports also mitigates concerns that later volatility flags are stale and uninformative because of the on-going adoption of the risk-return framework by analysts. ${ }^{26}$ The reported coefficients highlight two key results, regardless of sample considered. First, Morgan Stanley's volatility flags were not strong predictors of the variance of long-run base case valuation errors. Second, after controlling for these volatility flags, the spread in the analysts' scenario-based valuations continues to display a strong positive relation with future absolute unexpected price movements.

\section{Conclusion}

In this paper, we document that analysts are able to assess and identify long-term risk in the form of potential shocks to the firm's fundamentals and the variance of future long-run return payoffs. Our analysis provides several important contributions to the literature. First, these results show that analyst's scenario-based valuation estimates reflect and convey information about the riskiness of the covered firm. We view our paper as distinct from earlier work on analysts' equity risk ratings and filling a large void in the extant literature on how analysts incorporate information about state-contingent valuation risk into their investment theses. By focusing on a distributional characteristic of actual scenario-based valuation estimates, we are able to gauge the ex post accuracy of an individual analyst's base case forecast and examine whether the magnitude and sign of base case valuation errors are correlated with the form and nature of the analyst's ex ante risk-return assessments. This approach provides greater detail about the link between analyst's risk assessment and future outcomes.

Second, the paper provides an important first step in understanding how an individual analyst assesses the riskiness of the company's fundamentals and incorporates that information into the valuation

\footnotetext{
${ }^{26}$ Descriptively, for this sample period, $76.7 \%$ of the covered firms were flagged as "high volatility stocks." Such relative overweighting is not unexpected given (1) the analyst community's bias to cover high growth firms and (2) the heightened macro-economic risk that existed during calendar years 2007 and 2008.
} 
process through the use of a new set of publicly available data. Our evidence suggests that contextual information about future fundamentals influence the analyst's assessment of the distribution of long-term valuation payoffs. Future research can use this data to explore these issues further, including an examination of how these assessments are differentially shaped by firm, industry, market, and macroeconomic factors across firms and over time.

Lastly, the descriptive data presented in the paper raises numerous questions about the influence of analyst behavioral biases on their assessment of the risk-return potential of covered firms. For example, the average base case valuation estimate in our sample is not only optimistic, but asymmetrically tilted towards the analyst's bull case valuation. Is such a tilt the result of a selection bias in analyst coverage, an optimistic bias in their forecasts or beliefs, or a natural artifact of the risk-return tradeoff? Similarly, our descriptive evidence suggest that forecasting behavior changed in response to the recent financial crisis, raising numerous questions about the extent to which analysts' risk and payoff assessments are unduly influenced by recent experience. We believe that the descriptive evidence in our paper will serve as a foundation for interesting and insightful future research about the valuation activities of equity analysts. 


\section{References}

Asquith, P., M.B. Mikhail, and A. Au, 2005. Information Content of Equity Analyst Reports. Journal of Financial Economics 75 (1), 245-282.

Barber, B., Lehavy, R., McNichols, M., and B. Trueman, 2001. Can investors profit from the prophets? Consensus analyst recommendations and stock returns. The Journal of Finance 56 (2), 773-806.

Beaver, W., Kettler, P., and M. Scholes, 1970. The association between market determined and accounting determined risk measures. The Accounting Review (October), 654-82.

Beyer, A., Cohen, D., Lys, T. and B. Walther, 2010. The financial reporting environment: Review of the recent literature. Journal of Accounting and Economics 50 (2/3), 296-343.

Bonini, S., L. Zanetti, R. Bianchini and A. Salvi, 2010. Target price accuracy in Equity Research. Journal of Business, Finance and Accounting 37(9/10), 1177-1217.

Bradshaw, M.T., 2002. The Use of Target Prices to Justify Sell-Side Analysts' Stock Recommendations. Accounting Horizons 16 (March), 27-41.

Bradshaw, M.T., L.D. Brown, and K. Huang, 2013. Do Sell-Side Analysts Exhibit Differential Target Price Forecasting Ability? Review of Accounting Studies 18, 930-955.

Bradshaw, M.T., A.G. Huang, and H. Tan, 2012. Analyst Target Price Optimism around the World. Working paper, Boston College (August).

Brav, A. and R. Lehavy, 2003. An Empirical Analysis of Analysts' Target Prices: Short-Term Informativeness and Long-term Dynamics. The Journal of Finance 58 (5), 1933-1967.

Brown, L.D., and M.S. Rozeff, 1978. The Superiority of Analyst Forecasts as Measures of Expectations: Evidence from Earnings. The Journal of Finance 33, 1-16.

Brown, L.D., P. A Griffin, R. L. Hagerman and M. E. Zmijewski, 1987. Security Analyst Superiority Relative to Univariate Time-Series Models in Forecasting Quarterly Earnings. Journal of Accounting and Economics 9 (1), 61-87.

Chen, J., Hong, H., and J. Stein, 2001. Forecasting crashes: Trading volume, past returns, and conditional skewness in stock prices. Journal of Financial Economics 61, 345-381.

Daniel, K., and S. Titman, 2006. Market Reactions to Tangible and Intangible Information. The Journal of Finance 61 (4), 1605-1643.

Demirakos, E., N. Strong, and M. Walker, 2010. Does valuation model choice affect target price accuracy? European Accounting Review 19 (1), 35-72.

Diether, K., Malloy, C. and A. Scherbina, 2002. Differences of opinion and the cross-section of stock returns. The Journal of Finance 57, 2113-2141.

Fama, E. and K. French, 1992. The cross-section of expected stock returns. The Journal of Finance 47, 427- 465 . 
Frankel, R. and C.M. Lee. 1998. Accounting Valuation, market expectation, and cross-sectional stock returns. Journal of Accounting and Economics 25, 283-319.

Fried, D. and D. Givoly. 1982. Financial Analysts' Forecasts of Earnings: A Better Surrogate for Market Expectations. Journal of Accounting and Economics 4 (2), 85-107.

Givoly, D. and J. Lakonishok, 1979. The information content of financial analysts' forecasts of earnings. Journal of Accounting and Economics 1, 165-185.

Gleason, C., W.B. Johnson, H. Li, 2013. Valuation model use and the price target performance of sellside equity analysts. Contemporary Accounting Review 30 (1), 80-115.

Harvey, C.R., and A. Siddique, 2000. Conditional skewness in asset pricing tests. The Journal of Finance 55 (3), 1263-1295.

Johnson, T.C., 2004. Forecast dispersion and the cross-section of expected returns. The Journal of Finance 59, 1957-1978.

Lakonishok, J., A. Shleifer, and R. Vishny. 1994. Contrarian Investment, Extrapolation and Risk. The Journal of Finance 44 (5), 1541-1578.

Lin, H., 1994. Security Analysts' Investment Recommendations. Ph.D. dissertation, Stanford University.

Lui, D., Markov, S., and A. Tamayo, 2007. What makes a stock risky? Evidence from sell-side analysts' risk ratings. Journal of Accounting Research 45, 629-665.

Lui, D., Markov, S., and A. Tamayo, 2012. Equity analysts and the market's assessment of risk. Journal of Accounting Research 50 (5), 1287-1317.

McNichols, M. and P. O’Brien, 1997. Self-Selection and Analyst Coverage. Journal of Accounting Research, 35, 167-199.

O'Brien, P. C., 1988. Analysts' forecasts as earnings expectations. Journal of Accounting and Economics $10,53-83$.

Penman, S.H. 2010. Financial Forecasting, Risk and Valuation: Accounting for the Future. Abacus, 46(2), 211-228.

Ramnath, S, Rock, S. and P. Shane, 2008. The financial analyst forecasting literature: A taxonomy with suggestions for further research. International Journal of Forecasting 24: 34-75.

Rosenberg, B. and V. Marathe, 1975. The Prediction of Investment Risk: Systematic and Residual Risk. Proceedings of the Seminar in the Analysis of Security Prices, University of Chicago, November, 1975.

Srinivasan, S., and D. Lane, 2011. The Risk-Reward Framework at Morgan Stanley Research. Harvard Business School Case 111-011.

Stickel, S.E., 1995. The Anatomy of the Performance of Buy and Sell Recommendations. Financial Analysts Journal, 51(5), 25-39. 
Weyns, G., J.-L. Perez, and V. Jenkins, 2007. Risk-Reward Views: Unlocking the Full Potential of Fundamental Analysis. Morgan Stanley Global Research, December 17, 2007.

Womack, K.L., 1996. Do Brokerage Analysts' Recommendations Have Investment Value? The Journal of Finance (March): 137-167.

Zhang, X.F., 2006. Information Uncertainty and Stock Returns. The Journal of Finance 61 (1), 105-137.

Zmijewski, M., 1993. Comments on 'Earnings forecasting research: its implications for capital markets research’ by L. Brown. International Journal of Forecasting 9, 337-342. 


\section{Appendix 1 Variable Definitions}

\begin{tabular}{|c|c|c|}
\hline Variable & Definition & Data Source \\
\hline Base $_{i, t}$ & $\begin{array}{l}\text { The "base case" value forecast contained in the first Morgan Stanley analyst report } \\
\text { issued for firm I in quarter t. }\end{array}$ & Morgan Stanley \\
\hline Bull $_{i, t}$ & $\begin{array}{l}\text { The "bull case" value forecast issued in the first Morgan Stanley analyst report for firm i } \\
\text { in quarter t. }\end{array}$ & Morgan Stanley \\
\hline Bear $_{i, t}$ & $\begin{array}{l}\text { The "bear case" value forecast issued in the first Morgan Stanley analyst report for firm i } \\
\text { in quarter } t \text {. }\end{array}$ & Morgan Stanley \\
\hline Base Return $_{i, t}$ & $\begin{array}{l}\text { The expected return (excluding dividends) to investing in the firm at the time of the } \\
\text { analyst report, measured as } \text { Base }_{i, t} \text { minus } \text { Price }_{i, t} \text {, scaled by } \text { Price }_{i, t} \text {, where } \text { Price }_{i, t} \text { is the } \\
\text { closing stock price on the day before the release of the analyst report. }\end{array}$ & $\begin{array}{l}\text { Morgan Stanley, } \\
\text { FactSet }\end{array}$ \\
\hline BullReturn $_{i, t}$ & Idem as BaseRet $t_{i, t}$ only referring to $B u l l_{i, t}$ & $\begin{array}{l}\text { Morgan Stanley, } \\
\text { FactSet }\end{array}$ \\
\hline Bear Return $_{i, t}$ & Idem as BearRet $_{i, t}$ only referring to Bear $_{i, t}$ & $\begin{array}{l}\text { Morgan Stanley, } \\
\text { FactSet }\end{array}$ \\
\hline $\begin{array}{l}\text { Spread }_{i, t} \\
\text { SpreadP }_{i, t}\end{array}$ & 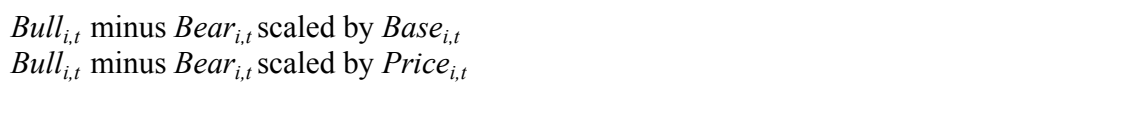 & $\begin{array}{l}\text { Morgan Stanley } \\
\text { Morgan Stanley, } \\
\text { FactSet }\end{array}$ \\
\hline Raw Return $_{i, t}$ & $\begin{array}{l}\text { The realized return (excluding dividends) over the one-year ( } 365 \text { day) interval following } \\
\text { report publication. Measured as Price }{ }_{i, t+365} \text { minus } \text { Price }_{i, t} \text {, scaled by Price } \text { Pr,t }_{i, t} \text { where } \\
\text { Price }_{i, t+365} \text { and } \text { Price }_{i, t} \text { are the closing stock prices on day } 365 \text { post-release and on the day } \\
\text { before the release of the analyst report, respectively. }\end{array}$ & FactSet \\
\hline $\begin{array}{l}\text { Unanticipated } \\
\text { Return }_{i, t}\end{array}$ & $\begin{array}{l}\text { The unanticipated return to the analyst's base case forecast (excluding dividends) over } \\
\text { the one-year interval post-report publication. Measured as Raw Return }{ }_{i, t} \text { minus Base } \\
\text { Return }_{\mathrm{i}, \mathrm{t}}\end{array}$ & $\begin{array}{l}\text { Morgan Stanley, } \\
\text { FactSet }\end{array}$ \\
\hline $\begin{array}{l}\mid \text { Unanticipated } \\
\text { Return }_{i, t} \mid\end{array}$ & Absolute value of Unanticipated Return $n_{i, t}$ & $\begin{array}{l}\text { Morgan Stanley, } \\
\text { FactSet }\end{array}$ \\
\hline Firm Size Sitt & Market value of the firm & FactSet \\
\hline Beta $_{i, t}$ & $\begin{array}{l}\text { Beta of the firm relative to the S\&P500 (measured as the slope in a weekly return } \\
\text { regression over the } 60 \text { weeks before the release of the report) }\end{array}$ & FactSet \\
\hline IdioRisk $_{i, t}$ & $\begin{array}{l}\text { Natural } \log \text { of the ratio }\left(1-R^{2}\right) / R^{2} \text { where } R^{2} \text { is the } R^{2} \text { from a regression of weekly firm- } \\
\text { returns on the weekly } S \& P 500 \text { returns, measured over the } 52 \text { week interval before } \\
\text { release of the report }\end{array}$ & FactSet \\
\hline$B T M_{i, t}$ & Ratio of common equity to market value of the firm & $\begin{array}{l}\text { Worldscope, } \\
\text { FactSet }\end{array}$ \\
\hline Leverage $_{i, t}$ & Ratio of Long-term and Short-term debt to Common Equity & $\begin{array}{l}\text { Worldscope, } \\
\text { FactSet }\end{array}$ \\
\hline EarnVol $_{i, t}$ & Coefficient of variation of past 20 quarterly EPS & $\begin{array}{l}\text { Worldscope, } \\
\text { FactSet }\end{array}$ \\
\hline $\operatorname{NegEarn}_{i, t}$ & $\begin{array}{l}\text { Indicator variable equal to } 1 \text { if the sum of the past } 4 \text { quarterly earnings is negative, and } 0 \\
\text { otherwise }\end{array}$ & $\begin{array}{l}\text { Worldscope, } \\
\text { FactSet }\end{array}$ \\
\hline $\operatorname{Neg} B V_{i . t}$ & Indicator variable equal to 1 if Common equity is negative, and 0 otherwise & $\begin{array}{l}\text { Worldscope, } \\
\text { FactSet }\end{array}$ \\
\hline$\triangle R O E$ & $\begin{array}{l}\text { One-year-ahead, seasonally-adjusted change in ROE, measured as the ROE in quarter } \\
\mathrm{t}+4 \text { minus and ROE quarter t. ROE is measured as the ratio of quarterly net income } \\
\text { available to common shareholders, scaled by average common equity over quarter t. }\end{array}$ & $\begin{array}{l}\text { Worldscope, } \\
\text { FactSet }\end{array}$ \\
\hline$\Delta$ Margin & $\begin{array}{l}\text { One-year-ahead, seasonally-adjusted change in operating margin, measured as operating } \\
\text { margin in quarter } \mathrm{t}+4 \text { minus operating margin in quarter t. Operating margin is } \\
\text { measured as operating income to sales. }\end{array}$ & $\begin{array}{l}\text { Worldscope, } \\
\text { FactSet }\end{array}$ \\
\hline Growth & $\begin{array}{l}\text { One-year-ahead, seasonally-adjusted growth in revenue, measured as the ratio of sales in } \\
\text { quarter } t+4 \text { to sales in quarter } t \text {. }\end{array}$ & $\begin{array}{l}\text { Worldscope, } \\
\text { FactSet }\end{array}$ \\
\hline Dispersion_FY1 & The standard deviation of one-year-ahead earnings forecasts on IBES, scaled by the & $\mathrm{I} / \mathrm{B} / \mathrm{E} / \mathrm{S}$ \\
\hline
\end{tabular}


consensus FY1 earnings forecast, during the month the analyst report is released.

Dispersion_FY2 The standard deviation of two-year-ahead earnings forecasts on IBES, scaled by the

$\mathrm{I} / \mathrm{B} / \mathrm{E} / \mathrm{S}$ consensus FY2 earnings forecast, during the month the analyst report is released.

Volatility Flag

An indicator variable equal to one if the analyst had an outstanding volatility flag on the covered firm at the time the investment report is issued, zero otherwise.

Morgan Stanley 


\section{Appendix 2 \\ Example of Morgan Stanley Risk-Return Forecast \\ Netflix (NFLX, \$153, Overweight)}

\section{Risk-Reward View: Secular Growth Thesis Intact}

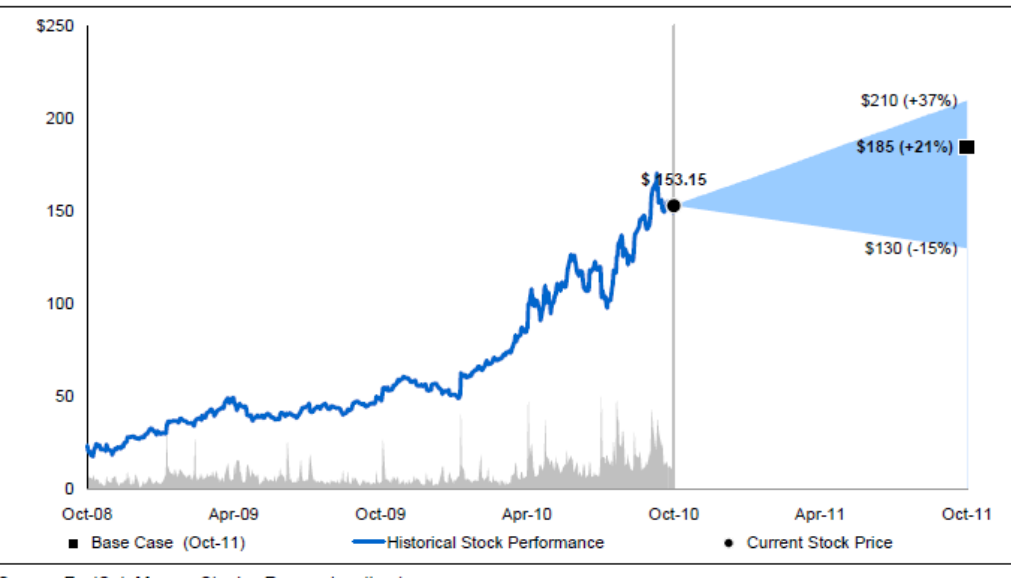

Source: FactSet, Morgan Stanley Research estimates

\begin{tabular}{|c|c|c|}
\hline \multicolumn{2}{|c|}{ Fair Value $\$ 185$} & $\begin{array}{l}\text { Fair value of } \$ 185 \text { is based on our DCF model } \\
\text { Accelerated share gains + margin expansion as Netflix keeps }\end{array}$ \\
\hline $\begin{array}{l}\text { Bull } \\
\text { Case } \\
\$ 210\end{array}$ & $\begin{array}{l}\text { 17x Upside } \\
\text { Case C12e } \\
\text { EV / EBITDA }\end{array}$ & $\begin{array}{l}\text { Accelerated share gains + margin expansion as Netflix keeps } \\
\text { digital competitors at bay; material international contribution. } \\
\text { Continued lead in digital video monetization. } 5 \text {-year revenue } \\
\text { CAGR of } 21 \% \text { (C2010E-C2015E), operating margin of } 26 \% \text { by } \\
\text { C2015E. }\end{array}$ \\
\hline $\begin{array}{l}\text { Base } \\
\text { Case } \\
\$ 185\end{array}$ & $\begin{array}{l}\text { 17x Base } \\
\text { Case C12e } \\
\text { EV / EBITDA }\end{array}$ & $\begin{array}{l}\text { Subscriber growth continues to accelerate, margins improve } \\
\text { long-term on fixed-cost leverage. Subscriber growth accelerates } \\
\text { to }+60 \% \text { Y } / \text { in CQ4E, streaming content costs increase to } ~ 20 \% \\
\text { of revenue by CQ4E. 5-year revenue CAGR of } 21 \% \\
\text { (C2010E-C2015E), operating margin of } 24 \% \text { by C2015E. }\end{array}$ \\
\hline $\begin{array}{l}\text { Bear } \\
\text { Case } \\
\$ 130\end{array}$ & $\begin{array}{l}16 x \\
\text { Downside } \\
\text { Case C12e } \\
\text { EV / EBITDA }\end{array}$ & $\begin{array}{l}\text { Strong competition from kiosks and digital, margins } \\
\text { pressured from costs of digital streaming content. Competition } \\
\text { from kiosks / VOD pressure share gains. } 5 \text {-year revenue CAGR of } \\
19 \% \text { (C2010E-C2015E), operating margin of } 22 \% \text { by C2015E. }\end{array}$ \\
\hline
\end{tabular}

\section{SWOT Analysis - Netflix}

\begin{tabular}{|c|c|}
\hline $\begin{array}{l}\text { Strengths } \\
\text { 1. Market / brand leadership in subscription-based } \\
\text { online streaming and DVD-by-mail } \\
\text { 2. Strong value proposition with "all-you-can-eat" } \\
\text { subscription plans and hybrid distribution } \\
\text { 3. Broadest digital device penetration among } \\
\text { streaming providers }\end{array}$ & $\begin{array}{l}\text { Weaknesses } \\
\text { 1. Delivery by mail does not offer instant gratification } \\
\text { 2. Some competitors offer new releases to } \\
\text { customers } 28 \text {-days earlier than Netflix }\end{array}$ \\
\hline $\begin{array}{l}\text { Opportunities } \\
\text { 1. Continued subscriber growth acceleration due to } \\
\text { success with digital streaming product } \\
\text { 2. Operating margin expansion as model shifts to } \\
\text { digital } \\
\text { 3. International expansion }\end{array}$ & $\begin{array}{l}\text { Threats } \\
\text { 1. Competitive threat from the kiosk business model } \\
\text { 2. Long term risk from consumer shift to digital } \\
\text { streaming including competing offers, such as } \\
\text { cable + satellite VOD / Amazon VOD / Apple } \\
\text { iTunes / Hulu Plus / Wal-Mart + Vudu / Best Buy } \\
\text { CinemaNow }\end{array}$ \\
\hline
\end{tabular}

\section{Why Overweight?}

- Investment in digital has significantly increased Netflix's consumer value proposition. Addressable market expands well beyond DVD rental

- As more business shifts to digital, there is an opportunity to expand margins while continuing to improve content. Netflix op. margin of $12.6 \%$ in C2010E, vs. premium TV at $25-30 \%+$

- Netflix has created a scale-based competitive advantage around user experience and monetization of content that otherwise has limited value in the supply chain.

\section{Key Value Drivers}

- Strong growth in ending subscribers (+52\% $Y / Y$ in CQ3)

- Expanding operating margin (12.6\% in CQ3 vs. $11.7 \%$ in CQ3:09)

- Declining subscriber acquisition cost (SAC), we estimate $\$ 19.93$ per gross subscriber add in C2010E $(-22 \% \mathrm{Y} / \mathrm{Y})$

- Netflix streaming device / content deals improve value proposition

\section{Potential Catalysts}

- Uptake of digital offering on iPad / video game consoles / Apple TV

- Licensing deals with studios that increase streaming content library

- Streaming-only plan launch in the USA

\section{Key Questions}

- How will the shift to digital streaming impact Netflix? Specifically, what impact will content deals have on gross margin?

-Will studios become more receptive of Netflix as a revenue stream?

\section{Key Risks}

- Competitive threat from the kiosk business model / increasing competition in digital video - Rising digital content licensing costs

Extract from Morgan Stanley analyst report on Netflix Inc dated October 21, 2010

For this investment report:

Bull $_{i, t}=210 ;$ Base $_{i, t}=185 ;$ Bear $_{i, t}=150 ;$ Price in advance of report date $=153.15$. One-year-ahead Price $=117.04$

Base Return $_{i, t}=20.80 \%$; Bull Return ${ }_{i, t}=37.12 \%$; Bear Return ${ }_{i, t}=-15.12 \%$ Spread $_{i, t}=(210-150) / 185=0.3243$

Unanticipated Return ${ }_{i, t}=(117.04-185.00) / 153.15=-44.37 \%$ 


\section{Table 1}

\section{Analysts’ scenario-based valuation estimates: Descriptive statistics}

This table presents descriptive evidence on the characteristics of analysts' scenario-based value estimates (i.e., base case, bull case, and bear case valuations), their assessments of firm risk / valuation uncertainty (i.e., the spread in the analyst's scenario-based valuations) and their ex post accuracy over the sample period January 2007 to December 2010. Panel A presents descriptive statistics for the full sample; panels B and $\mathrm{C}$ present mean characteristics across GICS sector classifications and year-quarters, respectively. $\mathrm{N}=6,029$

Panel A: Characteristics of analyst scenario-based value estimates and the ex post accuracy of base case valuations

\begin{tabular}{|c|c|c|c|c|c|c|c|c|c|c|c|}
\hline & Mean & StdDev & Min & $1 \%$ & $10 \%$ & $25 \%$ & Median & $75 \%$ & $90 \%$ & $99 \%$ & Max \\
\hline \multicolumn{12}{|l|}{ Ex ante characteristics } \\
\hline Base Return & 0.159 & 0.282 & -0.788 & -0.352 & -0.094 & 0.025 & 0.122 & 0.239 & 0.417 & 1.174 & 4.986 \\
\hline Bull Return & 0.534 & 0.490 & -0.537 & 0.021 & 0.172 & 0.269 & 0.418 & 0.636 & 0.970 & 2.409 & 8.507 \\
\hline Bear Return & -0.270 & 0.179 & -1.000 & -0.815 & -0.501 & -0.366 & -0.247 & -0.152 & -0.079 & 0.093 & 1.235 \\
\hline Spread & 0.688 & 0.398 & 0.078 & 0.185 & 0.333 & 0.452 & 0.611 & 0.828 & 1.090 & 2.000 & 6.000 \\
\hline \multicolumn{12}{|l|}{ Ex post accuracy } \\
\hline Unanticipated Return & -0.062 & 0.572 & -3.887 & -1.241 & -0.675 & -0.389 & -0.087 & 0.206 & 0.535 & 1.574 & 8.296 \\
\hline |Unanticipated Return| & 0.404 & 0.409 & 0.000 & 0.006 & 0.055 & 0.139 & 0.311 & 0.552 & 0.854 & 1.744 & 8.296 \\
\hline
\end{tabular}

Panel B: Mean analyst scenario-based valuation characteristics by GCIS sector classification

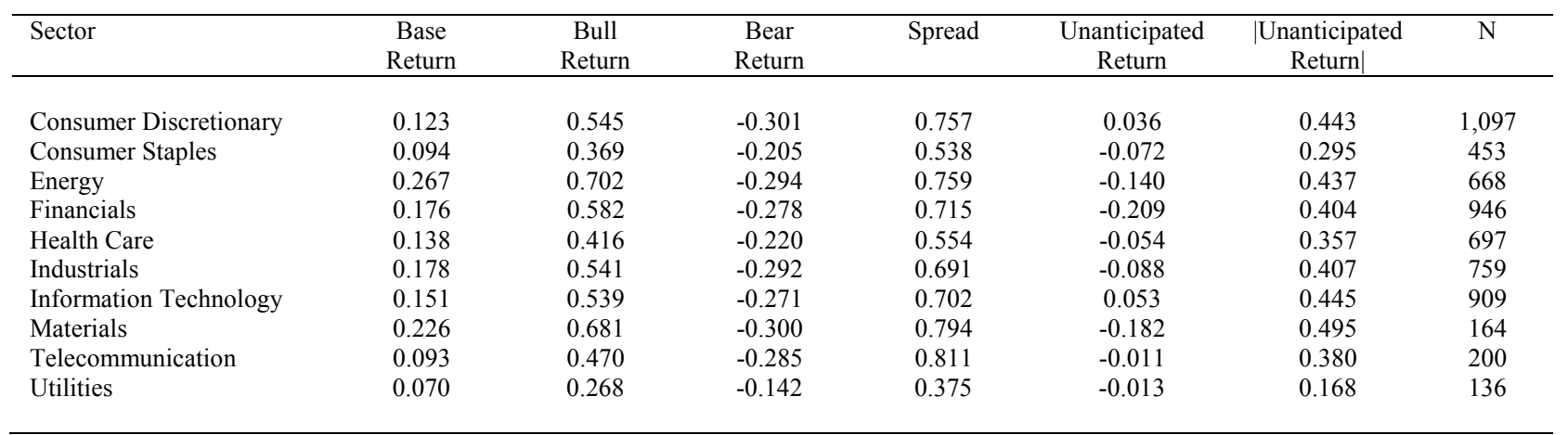


Table 1 (continued)

Analysts' scenario-based valuation estimations: Descriptive statistics

Panel C: Mean analyst scenario-based forecast characteristics by year-quarter

\begin{tabular}{|c|c|c|c|c|c|c|c|}
\hline Quarter & $\begin{array}{c}\text { Base } \\
\text { Return }\end{array}$ & $\begin{array}{c}\text { Bull } \\
\text { Return }\end{array}$ & $\begin{array}{c}\text { Bear } \\
\text { Return }\end{array}$ & Spread & $\begin{array}{c}\text { Unanticipated } \\
\text { Return }\end{array}$ & $\begin{array}{c}\text { |Unanticipated } \\
\text { Return } \mid\end{array}$ & $\mathrm{N}$ \\
\hline 2007 Q1 & 0.072 & 0.323 & -0.165 & 0.458 & -0.172 & 0.321 & 157 \\
\hline 2007 Q3 & 0.129 & 0.378 & -0.149 & 0.472 & -0.279 & 0.408 & 195 \\
\hline 2007 Q4 & 0.110 & 0.418 & -0.204 & 0.567 & -0.524 & 0.538 & 332 \\
\hline 2008 Q1 & 0.153 & 0.504 & -0.213 & 0.632 & -0.543 & 0.574 & 391 \\
\hline 2008 Q3 & 0.192 & 0.570 & -0.223 & 0.671 & -0.390 & 0.433 & 359 \\
\hline $2008 \mathrm{Q} 4$ & 0.332 & 0.864 & -0.280 & 0.849 & 0.031 & 0.403 & 469 \\
\hline 2009 Q1 & 0.300 & 0.883 & -0.342 & 0.917 & 0.361 & 0.607 & 436 \\
\hline 2009 Q2 & 0.131 & 0.633 & -0.391 & 0.933 & 0.379 & 0.529 & 373 \\
\hline 2009 Q3 & 0.127 & 0.520 & -0.338 & 0.761 & 0.074 & 0.327 & 429 \\
\hline 2009 Q4 & 0.124 & 0.502 & -0.318 & 0.728 & 0.067 & 0.307 & 517 \\
\hline 2010 Q1 & 0.125 & 0.464 & -0.288 & 0.660 & 0.102 & 0.293 & 552 \\
\hline $2010 \mathrm{Q} 2$ & 0.105 & 0.408 & -0.270 & 0.613 & 0.097 & 0.295 & 421 \\
\hline 2010 Q4 & 0.107 & 0.415 & -0.292 & 0.631 & -0.081 & 0.295 & 401 \\
\hline
\end{tabular}


Table 2

Firm characteristics and analysts' scenario-based value estimates

This table presents descriptive evidence on the characteristics of the firm-quarter observations associated with Morgan Stanley's analysts' scenario-base value estimates over the sample period January 2007 to December 2010. Panel A presents descriptive statistics for the full sample of firm-quarter observations. Panel B presents Spearman correlations between various analyst state-based forecast characteristics and these firm characteristics. $\mathrm{N}=6,029$.

\section{Panel A: Descriptive statistics on the sample of firm-quarter observations}

\begin{tabular}{|c|c|c|c|c|c|c|c|c|c|}
\hline & Mean & Std. Dev. & $1 \%$ & $10 \%$ & $25 \%$ & Median & $75 \%$ & $90 \%$ & $99 \%$ \\
\hline Firm Size & 17,633 & 38,633 & 198 & 884 & 2,072 & 5,629 & 16,317 & 38,818 & 188,691 \\
\hline Beta & 1.199 & 0.615 & 0.145 & 0.519 & 0.785 & 1.117 & 1.520 & 1.948 & 3.131 \\
\hline IdioRisk & 0.737 & 1.075 & -1.089 & -0.436 & 0.009 & 0.559 & 1.278 & 2.035 & 4.173 \\
\hline BTM & 0.561 & 0.639 & -0.196 & 0.142 & 0.261 & 0.435 & 0.711 & 1.068 & 2.643 \\
\hline Leverage & 0.988 & 3.691 & -2.507 & 0.000 & 0.1845 & 0.510 & 1.184 & 2.443 & 7.865 \\
\hline EarnVol & 1.174 & 54.510 & -7.533 & 0.118 & 0.226 & 0.367 & 0.616 & 1.135 & 11.723 \\
\hline NegEarn & 0.091 & 0.288 & 0.000 & 0.000 & 0.000 & 0.000 & 0.000 & 0.000 & 1.000 \\
\hline NegBV & 0.016 & 0.127 & 0.000 & 0.000 & 0.000 & 0.000 & 0.000 & 0.000 & 1.000 \\
\hline ROE & 0.029 & 0.145 & -0.349 & -0.025 & 0.012 & 0.031 & 0.054 & 0.089 & 0.310 \\
\hline$\triangle \mathrm{ROE}$ & -0.004 & 0.128 & -0.507 & -0.058 & -0.018 & -0.001 & 0.013 & 0.048 & 0.416 \\
\hline$\Delta$ Margin & -0.001 & 0.545 & -0.629 & -0.110 & -0.031 & 0.001 & 0.029 & 0.091 & 0.583 \\
\hline Growth & 0.106 & 0.616 & -0.553 & -0.189 & -0.049 & 0.060 & 0.176 & 0.378 & 1.344 \\
\hline Raw Return & 0.096 & 0.546 & -0.843 & -0.487 & -0.229 & 0.053 & 0.328 & 0.652 & 1.792 \\
\hline
\end{tabular}

Panel B: Correlation between analysts' scenario-based valuation forecasts and firm characteristics

\begin{tabular}{|c|c|c|c|c|c|c|c|c|c|c|c|c|c|}
\hline & FirmSize & Beta & IdioRisk & BTM & Leverage & EarnVol & NegEarn & NegBV & ROE & $\Delta \mathrm{ROE}$ & $\Delta$ Margin & Growth & Raw Return \\
\hline Base Return & 0.065 & 0.125 & -0.052 & 0.103 & 0.018 & 0.066 & 0.047 & -0.022 & -0.014 & -0.049 & 0.003 & 0.064 & 0.049 \\
\hline Spread & -0.383 & 0.439 & -0.101 & 0.213 & 0.014 & 0.183 & 0.288 & 0.053 & -0.320 & -0.147 & -0.123 & -0.134 & 0.214 \\
\hline Unanticip.Return & -0.178 & 0.054 & -0.191 & 0.054 & -0.063 & -0.026 & 0.008 & 0.032 & -0.083 & 0.008 & 0.026 & -0.149 & 0.670 \\
\hline |Unanticip.Return| & -0.158 & 0.184 & 0.109 & 0.038 & -0.015 & 0.116 & 0.113 & 0.007 & -0.102 & -0.098 & -0.075 & 0.058 & -0.138 \\
\hline
\end{tabular}




\section{Table 3}

\section{Determinants of the spread in analyst scenario-based value estimates}

This table presents select coefficients from pooled cross-sectional estimations of the following empirical model:

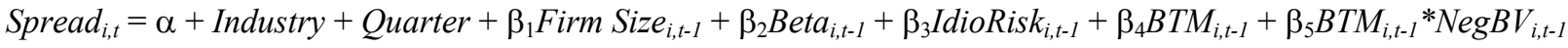

$$
\begin{aligned}
& +\beta_{6} \text { Leverage }_{i, t-1}+\beta_{7} \text { Leverage }_{i, t-1} * N e g B V_{i, t-1}+\beta_{8} \text { EarnVol }_{i, t-1}+\beta_{9} \operatorname{Neg}_{E_{a r n}}{ }_{i, t-1} \\
& +\beta_{10} \operatorname{Neg} B V_{i, t-1}+\beta_{11} \text { Base Return }_{i, t-1}+\varepsilon_{\mathrm{i}, \mathrm{t}}
\end{aligned}
$$

The dependent variable, Spread $_{i, t}$, is the difference between the analyst's bull case and bear case valuation estimates, scaled by the base case valuation, for firm i in quarter t. Industry is an array of nine industry indicator variables based on the firm's GICS sector classification. Quarter is an array of fifteen quarter-specific indicator variables. All other variables are defined in Appendix 1. T-statistics (in parentheses) are calculated using standard errors

\begin{tabular}{|c|c|c|c|c|}
\hline & $(1)$ & $(2)$ & (3) & $(4)$ \\
\hline Firm Size & $\begin{array}{l}- \\
-\end{array}$ & $\begin{array}{l}-0.035 \\
(-6.60)\end{array}$ & $\begin{array}{l}-0.026 \\
(-5.23)\end{array}$ & $\begin{array}{l}-0.024 \\
(-4.72)\end{array}$ \\
\hline Beta & $\begin{array}{c}0.229 \\
(12.31)\end{array}$ & $\begin{array}{l}0.163 \\
(9.25)\end{array}$ & $\begin{array}{l}0.137 \\
(9.23)\end{array}$ & $\begin{array}{l}0.143 \\
(9.24)\end{array}$ \\
\hline IdioRisk & $\begin{array}{l}0.065 \\
(8.05)\end{array}$ & $\begin{array}{l}0.038 \\
(4.96)\end{array}$ & $\begin{array}{l}0.034 \\
(4.83)\end{array}$ & $\begin{array}{l}0.036 \\
(5.08)\end{array}$ \\
\hline BTM & $\begin{array}{l}- \\
-\end{array}$ & $\begin{array}{l}0.178 \\
(7.32)\end{array}$ & $\begin{array}{l}0.166 \\
(7.26)\end{array}$ & $\begin{array}{l}0.174 \\
(7.54)\end{array}$ \\
\hline BTM*NegBV & - & $\begin{array}{l}-0.305 \\
(-2.94)\end{array}$ & $\begin{array}{l}-0.257 \\
(-2.92)\end{array}$ & $\begin{array}{l}-0.283 \\
(-3.20)\end{array}$ \\
\hline Leverage & $\begin{array}{l}- \\
-\end{array}$ & $\begin{array}{l}- \\
-\end{array}$ & $\begin{array}{l}0.006 \\
(2.29)\end{array}$ & $\begin{array}{l}0.006 \\
(2.30)\end{array}$ \\
\hline Leverage*NegBV & $\begin{array}{l}- \\
-\end{array}$ & $\begin{array}{l}- \\
-\end{array}$ & $\begin{array}{l}-0.009 \\
(-2.55)\end{array}$ & $\begin{array}{l}-0.010 \\
(-2.84)\end{array}$ \\
\hline EarnVol & $\begin{array}{l}- \\
-\end{array}$ & $\begin{array}{l}- \\
-\end{array}$ & $\begin{array}{l}-0.000 \\
(-0.54)\end{array}$ & $\begin{array}{l}-0.000 \\
(-0.62)\end{array}$ \\
\hline NegEarn & $\begin{array}{l}- \\
-\end{array}$ & $\begin{array}{l}- \\
-\end{array}$ & $\begin{array}{l}0.279 \\
(6.39)\end{array}$ & $\begin{array}{l}0.290 \\
(6.53)\end{array}$ \\
\hline NegBV & $\begin{array}{l}- \\
-\end{array}$ & $\begin{array}{l}0.069 \\
(0.93)\end{array}$ & $\begin{array}{l}0.034 \\
(0.37)\end{array}$ & $\begin{array}{l}0.021 \\
(0.22)\end{array}$ \\
\hline Base Return & $\begin{array}{l}- \\
-\end{array}$ & - & $\begin{array}{l}- \\
-\end{array}$ & $\begin{array}{l}-0.148 \\
(-2.46)\end{array}$ \\
\hline Constant & $\begin{array}{l}0.169 \\
(4.80)\end{array}$ & $\begin{array}{l}0.378 \\
(5.84)\end{array}$ & $\begin{array}{l}0.316 \\
(5.22)\end{array}$ & $\begin{array}{l}0.301 \\
(4.79)\end{array}$ \\
\hline $\begin{array}{l}\text { Industry Indicators } \\
\text { Quarter Indicators }\end{array}$ & $\begin{array}{l}\text { Included } \\
\text { Included }\end{array}$ & $\begin{array}{l}\text { Included } \\
\text { Included }\end{array}$ & $\begin{array}{l}\text { Included } \\
\text { Included }\end{array}$ & $\begin{array}{l}\text { Included } \\
\text { Included }\end{array}$ \\
\hline Adjusted $\mathrm{R}^{2}$ & 0.271 & 0.355 & 0.393 & 0.403 \\
\hline
\end{tabular}
clustered at the firm level. $\mathrm{N}=6,029$. 


\section{sted and realized returns conditional upon the spread in analysts' scenario-based value estimates}

ive statistics on the distribution of forecasted and future realized one-year-ahead equity returns, conditional upon the analyst's ut and risk surrounding firm value, as implied by the spread in the distribution of scenario-based value estimates. Spread $_{i, t}$, is defined he analyst's bull case and bear case valuation estimates, scaled by the base case valuation, for firm i in quarter t. Panel A presents the iation in stock price, excluding dividends, over the report's forecast horizon (Base Return $\left.{ }_{i, t}\right)$. Panel B presents statistics on these turns, inclusive of dividends, over the 365 day holding period (Raw Return ${ }_{i, t}$ ) across Spread $_{i, t}$ quintiles. Panel C presents the firm's equity (Unanticipated Return ${ }_{i, t}$ ) across Spread $_{i, t}$ quintiles, where Unanticipated Return $n_{i, t}$ is measured as the firm's realized raw $\mathrm{s}$ the forecasted return under the analyst's base case scenario $\left(\right.$ Base Return $\left._{i, t}\right)$. Panel D presents statistics on the distribution of the ated return realizations $\left(\mid{\left.\text { Unanticipated } \text { Return }_{i, t} \mid\right) \text { across Spread }}_{i, t}\right.$ quintiles. Panel E presents the mean and median value of Spread $_{i, t}$ nese mean and median realizations are monotonically increasing by construction. All future return metrics are measured over 365 issuance of the analyst's report. Each quarter, firms are assigned into Spread i, $_{\text {. }}$ quintiles based on that quarter's distribution of lues for differences in means (medians) are from a two-tailed t-test of means (signed rank wilcoxon test).

\begin{tabular}{|c|c|c|c|c|c|c|c|c|c|c|c|c|c|}
\hline \multicolumn{2}{|c|}{ 3ase Return } & \multicolumn{4}{|c|}{ Panel B: Raw Return } & \multicolumn{4}{|c|}{ Panel C: Unanticipated Return } & \multicolumn{4}{|c|}{ Panel D: Absolute Unanticipated Return } \\
\hline $\begin{array}{l}\text { Std. } \\
\text { Dev. }\end{array}$ & $\begin{array}{l}\text { Inter- } \\
\text { Quart. }\end{array}$ & Mean & Median & $\begin{array}{l}\text { Std. } \\
\text { Dev. }\end{array}$ & $\begin{array}{l}\text { Inter- } \\
\text { Quart. }\end{array}$ & Mean & Median & $\begin{array}{l}\text { Std. } \\
\text { Dev. }\end{array}$ & $\begin{array}{l}\text { Inter- } \\
\text { Quart. }\end{array}$ & Mean & Median & $\begin{array}{l}\text { Std. } \\
\text { Dev. }\end{array}$ & $\begin{array}{l}\text { Inter- } \\
\text { Quart. }\end{array}$ \\
\hline 0.127 & 0.136 & 0.036 & 0.047 & 0.340 & 0.411 & -0.071 & -0.058 & 0.360 & 0.464 & 0.281 & 0.225 & 0.235 & 0.284 \\
\hline 0.163 & 0.167 & 0.075 & 0.057 & 0.458 & 0.486 & -0.059 & -0.084 & 0.482 & 0.511 & 0.340 & 0.268 & 0.347 & 0.344 \\
\hline 0.234 & 0.212 & 0.090 & 0.053 & 0.496 & 0.584 & -0.080 & -0.094 & 0.527 & 0.573 & 0.392 & 0.305 & 0.360 & 0.440 \\
\hline 0.280 & 0.272 & 0.123 & 0.066 & 0.524 & 0.651 & -0.069 & -0.105 & 0.569 & 0.710 & 0.447 & 0.382 & 0.358 & 0.455 \\
\hline 0.469 & 0.406 & 0.161 & 0.044 & 0.803 & 0.786 & -0.032 & -0.126 & 0.823 & 0.832 & 0.564 & 0.437 & 0.601 & 0.518 \\
\hline 0.342 & 0.270 & 0.125 & -0.003 & 0.463 & 0.375 & 0.039 & -0.068 & 0.463 & 0.368 & 0.283 & 0.212 & 0.366 & 0.234 \\
\hline - & - & $(0.000)$ & $(0.241)$ & . & - & $(0.130)$ & $(0.099)$ & - & - & $(0.000)$ & $(0.000)$ & - & . \\
\hline
\end{tabular}

lio Characteristics 


\section{Table 5}

\section{Relation between the spread in analysts' scenario-based value estimates and the magnitude of future absolute unexpected price changes: Multivariate analysis}

This table presents select coefficients from various pooled cross-sectional estimations of the following empirical model:

$$
\begin{aligned}
& \mid \text { Unanticipated Return }_{i, t} \mid=\alpha+\text { Industry }+ \text { Quarter }+\beta_{1} \text { Spread }_{i, t}+\beta_{2} \text { Base Return }_{i, t-1}+\beta_{3} \text { Firm Size }_{i, t-1}+\beta_{4} \text { Beta }_{i, t-1} \\
& +\beta_{5} \text { IdioRisk }_{i, t-1}+\beta_{6} \text { BTM }_{i, t-1}+\beta_{7} B T M_{i, t-1} * N e g B V_{i, t-1}+\beta_{8} \text { Leverage }_{i, t-1}+\beta_{9} \text { Leverage }_{i, t-1} * N e g B V_{i, t-1} \\
& +\beta_{10} \text { EarnVol }_{i, t-1}+\beta_{11} \operatorname{NegEarn}_{i, t-1}+\beta_{12} N e g B V_{i, t-1}+\varepsilon_{\mathrm{i}, \mathrm{t}}
\end{aligned}
$$

The dependent variable is the absolute value of unanticipated return realizations $\left(\mid\right.$ Unanticipated Return $\left._{i, t} \mid\right)$, where Unanticipated Return $n_{i, t}$ is measured as the firm's realized raw return $\left(\right.$ Raw Return $\left._{i, t}\right)$ minus the forecasted return under the analyst's base case scenario (Base Return $n_{i, t}$ ). The first set of columns present coefficients from estimations using the full sample of analyst reports over the period 2007-2010. The second and third set of columns present coefficients from estimations excluding analyst reports written within one year of the start of the financial crisis (2007Q4-2008Q3) and excluding reports written during the financial crisis (2008Q4-2009Q2). Industry is an array of nine industry indicator variables based on the firm's GICS sector classification. Quarter is an array of fifteen

\begin{tabular}{|c|c|c|c|c|c|c|}
\hline & \multicolumn{4}{|c|}{$\begin{array}{l}\text { Full Sample } \\
(\mathrm{N}=6,029)\end{array}$} & \multirow[t]{2}{*}{$\begin{array}{c}\text { Excluding } \\
\text { Reports issued } \\
\text { in advance of } \\
\text { Financial Crisis } \\
(\mathrm{N}=4,570) \\
(5) \\
\end{array}$} & \multirow[t]{2}{*}{$\begin{array}{c}\text { Excluding } \\
\text { Reports issued } \\
\text { during } \\
\text { Financial Crisis } \\
(\mathrm{N}=4,751) \\
(6) \\
\end{array}$} \\
\hline & $(1)$ & $(2)$ & (3) & (4) & & \\
\hline Spread & $\begin{array}{c}0.279 \\
(11.22)\end{array}$ & $\begin{array}{l}0.244 \\
(8.21)\end{array}$ & $\begin{array}{l}0.181 \\
(5.54)\end{array}$ & $\begin{array}{l}0.166 \\
(4.67)\end{array}$ & $\begin{array}{l}0.210 \\
(5.26)\end{array}$ & $\begin{array}{l}0.109 \\
(4.77)\end{array}$ \\
\hline Base Return & $\begin{array}{l}0.298 \\
(8.22)\end{array}$ & $\begin{array}{l}0.281 \\
(5.88)\end{array}$ & $\begin{array}{l}0.256 \\
(5.18)\end{array}$ & $\begin{array}{l}0.249 \\
(4.93)\end{array}$ & $\begin{array}{l}0.152 \\
(2.41)\end{array}$ & $\begin{array}{c}0.423 \\
(11.56)\end{array}$ \\
\hline Firm Size & - & - & $\begin{array}{l}-0.018 \\
(-2.80)\end{array}$ & $\begin{array}{l}-0.016 \\
(-2.37)\end{array}$ & $\begin{array}{l}-0.019 \\
(-2.41)\end{array}$ & $\begin{array}{l}-0.013 \\
(-1.58)\end{array}$ \\
\hline Beta & - & $\begin{array}{l}0.055 \\
(4.11)\end{array}$ & $\begin{array}{l}0.036 \\
(2.46)\end{array}$ & $\begin{array}{l}0.032 \\
(2.27)\end{array}$ & $\begin{array}{l}0.030 \\
(1.76)\end{array}$ & $\begin{array}{l}0.029 \\
(2.31)\end{array}$ \\
\hline IdioRisk & - & $\begin{array}{l}0.021 \\
(3.29)\end{array}$ & $\begin{array}{l}0.011 \\
(1.54)\end{array}$ & $\begin{array}{l}0.011 \\
(1.54)\end{array}$ & $\begin{array}{l}0.017 \\
(1.99)\end{array}$ & $\begin{array}{l}0.023 \\
(3.09)\end{array}$ \\
\hline BTM & - & - & $\begin{array}{l}0.094 \\
(3.11)\end{array}$ & $\begin{array}{l}0.094 \\
(3.02)\end{array}$ & $\begin{array}{l}0.103 \\
(3.04)\end{array}$ & $\begin{array}{l}0.003 \\
(0.12)\end{array}$ \\
\hline BTM*NegBV & - & - & $\begin{array}{l}-0.187 \\
(-1.85)\end{array}$ & $\begin{array}{l}-0.117 \\
(-1.61)\end{array}$ & $\begin{array}{l}-0.185 \\
(-1.38)\end{array}$ & $\begin{array}{l}-0.099 \\
(-0.88)\end{array}$ \\
\hline Leverage & - & - & - & $\begin{array}{l}0.000 \\
(0.05)\end{array}$ & $\begin{array}{l}0.002 \\
(0.54)\end{array}$ & $\begin{array}{l}-0.000 \\
(-0.09)\end{array}$ \\
\hline Leverage*NegBV & - & - & - & $\begin{array}{l}-0.000 \\
(-0.12)\end{array}$ & $\begin{array}{l}-0.002 \\
(-0.45)\end{array}$ & $\begin{array}{l}0.001 \\
(0.19)\end{array}$ \\
\hline EarnVol & - & - & - & $\begin{array}{l}0.000 \\
(4.16)\end{array}$ & $\begin{array}{l}0.000 \\
(4.24)\end{array}$ & $\begin{array}{c}0.000 \\
(11.71)\end{array}$ \\
\hline NegEarn & - & - & - & $\begin{array}{l}0.076 \\
(1.64)\end{array}$ & $\begin{array}{l}0.060 \\
(1.14)\end{array}$ & $\begin{array}{l}0.095 \\
(1.97)\end{array}$ \\
\hline NegBV & - & - & $\begin{array}{l}0.024 \\
(0.26)\end{array}$ & $\begin{array}{l}0.018 \\
(0.16)\end{array}$ & $\begin{array}{l}0.027 \\
(0.20)\end{array}$ & $\begin{array}{l}0.006 \\
(0.04)\end{array}$ \\
\hline Constant & $\begin{array}{l}0.027 \\
(1.20)\end{array}$ & $\begin{array}{l}-0.005 \\
(-0.19)\end{array}$ & $\begin{array}{l}0.114 \\
(1.85)\end{array}$ & $\begin{array}{l}0.104 \\
(1.67)\end{array}$ & $\begin{array}{l}0.107 \\
(1.46)\end{array}$ & $\begin{array}{l}0.160 \\
(2.09)\end{array}$ \\
\hline $\begin{array}{l}\text { Industry Indicators } \\
\text { Quarter Indicators }\end{array}$ & $\begin{array}{l}\text { Included } \\
\text { Included }\end{array}$ & $\begin{array}{l}\text { Included } \\
\text { Included }\end{array}$ & $\begin{array}{l}\text { Included } \\
\text { Included }\end{array}$ & $\begin{array}{l}\text { Included } \\
\text { Included }\end{array}$ & $\begin{array}{l}\text { Included } \\
\text { Included }\end{array}$ & $\begin{array}{l}\text { Included } \\
\text { Included }\end{array}$ \\
\hline Adjusted $\mathrm{R}^{2}$ & 0.191 & 0.197 & 0.217 & 0.220 & 0.205 & 0.215 \\
\hline
\end{tabular}
quarter-specific indicator variables. All other variables are defined in Appendix 1. T-statistics (in parentheses) are calculated using standard errors clustered at the firm level. 


\section{Table 6}

\section{Relation between the characteristics of analysts' scenario-based value estimates and future innovations in firm fundamentals}

This table presents descriptive statistics on the distribution of future innovations to firm fundamentals, conditional upon the analyst's ex ante level of uncertainty about future firm value $\left(\operatorname{Spread}_{i, t}\right)$. $\operatorname{Spread}_{i, t}$, is defined as the difference between the analyst's bull case and bear case valuation estimates, scaled by the base case valuation, for firm $\mathrm{i}$ in quarter $\mathrm{t}$. Panel A presents the absolute one-year-ahead seasonally-adjusted change in each firms' quarterly return on equity $\left(\triangle R O E_{i, t}\right)$, operating profit margin $\left(\triangle \operatorname{Margin}_{i, t}\right)$ and revenue $\left(\operatorname{Growth}_{i, t}\right)$ realizations across $\operatorname{Spread}_{i, t}$ quintiles. P-values for differences in means are from a one-tailed t-test of means. Panel B presents select coefficients from pooled cross-sectional estimations of the following empirical model:

$$
\mid \text { Outcome }_{i, t+4} \mid=\alpha+\text { Industry }_{\mathrm{i}, \mathrm{t}}+\text { Quarter }_{\mathrm{i}, \mathrm{t}}+\beta_{1} \text { Spread }_{i, t}+\beta_{2} \text { Outcome }_{i, t}+\varepsilon_{\mathrm{i}, \mathrm{t}}
$$

In these estimations, the dependent variable Outcome $_{i, t+4}$ is the absolute value of one of the three preceding oneyear-ahead accounting realizations. Industry $y_{i}$ is an array of nine industry indicator variables based on the firm's GICS sector classification. Quarter $t_{t}$ is an array of fifteen quarter-specific indicator variables. All other variables are defined in Appendix 1. T-statistics in Panel B (in parentheses) are calculated using standard errors clustered at the firm level.

\section{Panel A: Change in firm fundamentals conditional upon Spread $_{i, t}$}

\begin{tabular}{|c|c|c|c|c|c|c|}
\hline \multirow[b]{2}{*}{ Dependent Variable: } & \multicolumn{3}{|c|}{ Full Sample } & \multicolumn{3}{|c|}{ Excluding Reports Impacted by the Financial Crisis } \\
\hline & $\left|\Delta \mathrm{ROE}_{\mathrm{i}, \mathrm{t}+4}\right|$ & $\mid \Delta$ Margin $_{i, t+4 \mid}$ & $\mid$ Growth $_{\mathrm{i}, t+4 \mid}$ & $\mid \Delta \mathrm{ROE}_{\mathrm{i}, \mathrm{t}+4 \mid}$ & $\mid \Delta$ Margin $_{i, t+4} \mid$ & $\mid$ Growth $_{i, t+4 \mid}$ \\
\hline Quintile: & & & & & & \\
\hline Low (1) & 0.036 & 0.059 & 0.145 & 0.032 & 0.045 & 0.144 \\
\hline (2) & 0.037 & 0.064 & 0.164 & 0.030 & 0.053 & 0.161 \\
\hline (3) & 0.039 & 0.068 & 0.175 & 0.026 & 0.055 & 0.168 \\
\hline (4) & 0.049 & 0.094 & 0.192 & 0.043 & 0.070 & 0.188 \\
\hline $\operatorname{High}(5)$ & 0.076 & 0.138 & 0.232 & 0.055 & 0.112 & 0.232 \\
\hline $\begin{array}{l}(5)-(1) \\
(p-v a l u e)\end{array}$ & $\begin{array}{c}0.040 \\
(0.000)\end{array}$ & $\begin{array}{c}0.079 \\
(0.000)\end{array}$ & $\begin{array}{c}0.087 \\
(0.000)\end{array}$ & $\begin{array}{c}0.023 \\
(0.000)\end{array}$ & $\begin{array}{c}0.067 \\
(0.000)\end{array}$ & $\begin{array}{c}0.088 \\
(0.000)\end{array}$ \\
\hline
\end{tabular}

Panel B: Multivariate analysis after controlling for historical firm performance

\begin{tabular}{|c|c|c|c|c|c|c|}
\hline \multirow[b]{2}{*}{ Dependent Variable: } & \multicolumn{3}{|c|}{ Full Sample } & \multicolumn{3}{|c|}{ Excluding Reports Impacted by the Financial Crisis } \\
\hline & $\left|\Delta \mathrm{ROE}_{\mathrm{i}, \mathrm{t}+4}\right|$ & $\mid \Delta$ Margin $_{i, t+4} \mid$ & $\mid$ Growth $_{\mathrm{i}, \mathrm{t}+4 \mid}$ & $\left|\Delta \mathrm{ROE}_{\mathrm{i}, \mathrm{t}+4}\right|$ & $\mid \Delta$ Margin $_{i, t+4} \mid$ & $\mid$ Growth $_{\mathrm{i}, \mathrm{t}+4 \mid}$ \\
\hline Spread $_{i, t}$ & $\begin{array}{l}0.025 \\
(3.92)\end{array}$ & $\begin{array}{l}0.056 \\
(3.71)\end{array}$ & $\begin{array}{l}0.036 \\
(2.87)\end{array}$ & $\begin{array}{l}0.019 \\
(2.28)\end{array}$ & $\begin{array}{l}0.065 \\
(3.92)\end{array}$ & $\begin{array}{l}0.051 \\
(2.53)\end{array}$ \\
\hline Outcome $_{\mathrm{i}, \mathrm{t}}$ & $\begin{array}{c}0.474 \\
(11.25)\end{array}$ & $\begin{array}{c}0.089 \\
(1.90)\end{array}$ & $\begin{array}{l}0.026 \\
(1.43)\end{array}$ & $\begin{array}{l}0.360 \\
(5.16)\end{array}$ & $\begin{array}{l}0.053 \\
(2.74)\end{array}$ & $\begin{array}{l}0.011 \\
(1.30)\end{array}$ \\
\hline Industry Indicators & Included & Included & Included & Included & Included & Included \\
\hline Quarter Indicators & Included & Included & Included & Included & Included & Included \\
\hline Adj. $R^{2}$ & 0.275 & 0.131 & 0.112 & 0.211 & 0.129 & 0.121 \\
\hline
\end{tabular}




\section{Table 7 \\ Impact of the Financial Crisis on Analysts’ Assessment of Valuation Uncertainty}

This table presents select coefficients from pooled cross-sectional estimations of the following empirical model:

$$
\begin{aligned}
& \text { Spread }_{i, t}=\alpha+\text { Industry }+\beta_{1} \text { Firm Size }_{i, t-1}+\beta_{2} \text { Beta }_{i, t-1}+\beta_{3} \text { IdioRisk }_{i, t-1}+\beta_{4} \text { BTM }_{i, t-1}+\beta_{5} B T M_{i, t-1} * N e g B V_{i, t-1} \\
& +\beta_{6} \text { Leverage }_{i, t-1}+\beta_{7} \text { Leverage }_{i, t-1} * N e g B V_{i, t-1}+\beta_{8} \text { EarnVol }_{i, t-1}+\beta_{9} \operatorname{NegEarn}_{i, t-1}+\beta_{10} \operatorname{NegBV}_{i, t-1}
\end{aligned}
$$

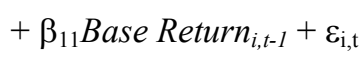

The dependent variable, Spread $_{i, t}$, is the difference between the analyst's bull case and bear case valuation estimates, scaled by the base case valuation, for firm $\mathrm{i}$ in quarter $\mathrm{t}$. The first and second columns (denoted Pre-Financial Crisis and Post-Financial Crisis, respectively) present coefficients from estimations using a sample of pre-financial crisis reports (issued before Q4 2008) and post-financial crisis reports (issued after Q3 2008), respectively. The last column presents the difference between the post and pre-financial crisis period coefficients. Differences between coefficients are tested using a spline regression specification. All other variables are defined in Appendix 1. T-

\begin{tabular}{|c|c|c|c|}
\hline & $\begin{array}{c}\text { Pre-Financial } \\
\text { Crisis } \\
\end{array}$ & $\begin{array}{c}\text { Post-Financial } \\
\text { Crisis } \\
\end{array}$ & $\begin{array}{c}\text { Difference } \\
\text { Post-Pre }\end{array}$ \\
\hline Firm Size & $\begin{array}{l}-0.030 \\
(-3.85)\end{array}$ & $\begin{array}{l}-0.025 \\
(-4.44)\end{array}$ & $\begin{array}{l}0.005 \\
(0.60)\end{array}$ \\
\hline Beta & $\begin{array}{l}0.094 \\
(5.54)\end{array}$ & $\begin{array}{l}0.157 \\
(6.72)\end{array}$ & $\begin{array}{l}0.063 \\
(2.38)\end{array}$ \\
\hline IdioRisk & $\begin{array}{l}0.012 \\
(1.49)\end{array}$ & $\begin{array}{l}0.028 \\
(3.04)\end{array}$ & $\begin{array}{l}0.015 \\
(1.30)\end{array}$ \\
\hline BTM & $\begin{array}{l}0.294 \\
(4.54)\end{array}$ & $\begin{array}{l}0.185 \\
(7.81)\end{array}$ & $\begin{array}{l}-0.109 \\
(-1.67)\end{array}$ \\
\hline BTM*NegBV & $\begin{array}{l}-0.507 \\
(-4.86)\end{array}$ & $\begin{array}{l}-0.269 \\
(-2.46)\end{array}$ & $\begin{array}{l}0.238 \\
(1.64)\end{array}$ \\
\hline Leverage & $\begin{array}{l}0.005 \\
(1.76)\end{array}$ & $\begin{array}{l}0.010 \\
(2.07)\end{array}$ & $\begin{array}{l}0.005 \\
(0.79)\end{array}$ \\
\hline Leverage*NegBV & $\begin{array}{l}-0.075 \\
(-2.58)\end{array}$ & $\begin{array}{l}-0.011 \\
(-2.10)\end{array}$ & $\begin{array}{l}0.064 \\
(2.23)\end{array}$ \\
\hline EarnVol & $\begin{array}{l}-0.002 \\
(-1.80)\end{array}$ & $\begin{array}{l}-0.000 \\
(-0.73)\end{array}$ & $\begin{array}{l}0.002 \\
(1.76)\end{array}$ \\
\hline NegEarn & $\begin{array}{l}0.337 \\
(3.15)\end{array}$ & $\begin{array}{l}0.249 \\
(6.05)\end{array}$ & $\begin{array}{l}-0.088 \\
(-0.88)\end{array}$ \\
\hline NegBV & $\begin{array}{l}-0.492 \\
(-2.24)\end{array}$ & $\begin{array}{l}0.105 \\
(1.16)\end{array}$ & $\begin{array}{l}0.597 \\
(2.75)\end{array}$ \\
\hline Base Return & $\begin{array}{l}-0.310 \\
(-3.54)\end{array}$ & $\begin{array}{l}-0.068 \\
(-1.19)\end{array}$ & $\begin{array}{l}0.242 \\
(2.77)\end{array}$ \\
\hline Constant & $\begin{array}{l}0.466 \\
(4.42)\end{array}$ & $\begin{array}{l}0.338 \\
(4.67)\end{array}$ & $\begin{array}{l}-0.127 \\
(-1.08)\end{array}$ \\
\hline Industry Indicators & Included & Included & - \\
\hline $\begin{array}{l}\text { Adjusted } \mathrm{R}^{2} \\
\text { Number of Obs. }\end{array}$ & $\begin{array}{l}0.320 \\
2,016\end{array}$ & $\begin{array}{l}0.357 \\
4,013\end{array}$ & $\begin{array}{l}- \\
-\end{array}$ \\
\hline
\end{tabular}
statistics (in parentheses) are calculated using standard errors clustered at the firm level. 


\section{Table 8}

\section{Impact of the Financial Crisis on mapping of uncertainty into absolute valuation errors}

This table presents select coefficients from pooled cross-sectional estimations of the following empirical model:

$$
\begin{aligned}
& \mid \text { Unanticipated Return }_{i, t} \mid=\alpha+\text { Industry }+\beta_{1} \text { Spread }_{i, t-1}+\beta_{2} \text { Base Return }_{i, t-1}+\beta_{3} \text { Firm Size }_{i, t-1}+\beta_{4} \text { Beta }_{i, t-1} \\
& +\beta_{5} \text { IdioRisk }_{i, t-1}+\beta_{6} B T M_{i, t-1}+\beta_{7} B T M_{i, t-1} * N e g B V_{i, t-1}+\beta_{8} \text { Leverage }_{i, t-1}+\beta_{9} \text { Leverage }_{i, t-1} * N e g B V_{i, t-1} \\
& +\beta_{10} \operatorname{EarnVol}_{i, t-1}+\beta_{11} N e g \operatorname{Earn}_{i, t-1}+\beta_{12} N e g B V_{i, t-1}+\varepsilon_{\mathrm{i}, \mathrm{t}}
\end{aligned}
$$

The dependent variable is the absolute value of unanticipated return realizations $\left(\mid\right.$ Unanticipated $\left._{\text {Return }}, t \mid\right)$, where Unanticipated Return $n_{i, t}$ is measured as the firm's realized raw return $\left(\operatorname{Raw}_{\text {Return }}{ }_{i, t}\right)$ minus the forecasted return under the analyst's base case scenario $\left(\right.$ Base Return $_{i, t}$ ). The first and second columns (denoted Pre-Financial Crisis and Post-Financial Crisis, respectively) present coefficients from estimations using a sample of pre-financial crisis reports (issued before Q4 2008) and post-financial crisis reports (issued after Q3 2008), respectively. The last column presents the difference between the post and pre-financial crisis period coefficients. Differences between

\begin{tabular}{|c|c|c|c|}
\hline & $\begin{array}{c}\text { Pre-Financial } \\
\text { Crisis }\end{array}$ & $\begin{array}{c}\text { Post-Financial } \\
\text { Crisis } \\
\end{array}$ & $\begin{array}{c}\text { Difference } \\
\text { Post-Pre }\end{array}$ \\
\hline Spread & $\begin{array}{l}0.119 \\
(4.98)\end{array}$ & $\begin{array}{l}0.266 \\
(6.63)\end{array}$ & $\begin{array}{l}0.147 \\
(3.30)\end{array}$ \\
\hline Base Return & $\begin{array}{c}0.806 \\
(19.33)\end{array}$ & $\begin{array}{l}0.163 \\
(2.68)\end{array}$ & $\begin{array}{l}-0.643 \\
(-9.31)\end{array}$ \\
\hline Firm Size & $\begin{array}{l}-0.002 \\
(-0.37)\end{array}$ & $\begin{array}{l}-0.020 \\
(-2.65)\end{array}$ & $\begin{array}{l}-0.018 \\
(-1.97)\end{array}$ \\
\hline Beta & $\begin{array}{l}0.063 \\
(3.88)\end{array}$ & $\begin{array}{l}0.010 \\
(0.52)\end{array}$ & $\begin{array}{l}-0.053 \\
(-2.16)\end{array}$ \\
\hline IdioRisk & $\begin{array}{l}-0.007 \\
(-1.04)\end{array}$ & $\begin{array}{l}0.010 \\
(1.02)\end{array}$ & $\begin{array}{l}0.017 \\
(1.40)\end{array}$ \\
\hline BTM & $\begin{array}{l}0.060 \\
(2.32)\end{array}$ & $\begin{array}{l}0.117 \\
(3.37)\end{array}$ & $\begin{array}{l}0.057 \\
(1.32)\end{array}$ \\
\hline BTM*NegBV & $\begin{array}{l}-0.200 \\
(-3.78)\end{array}$ & $\begin{array}{l}-0.194 \\
(-1.46)\end{array}$ & $\begin{array}{l}0.006 \\
(0.04)\end{array}$ \\
\hline Leverage & $\begin{array}{l}0.002 \\
(0.96)\end{array}$ & $\begin{array}{l}-0.000 \\
(-0.13)\end{array}$ & $\begin{array}{l}-0.002 \\
(-0.65)\end{array}$ \\
\hline Leverage*NegBV & $\begin{array}{l}-0.024 \\
(-1.49)\end{array}$ & $\begin{array}{l}0.000 \\
(0.16)\end{array}$ & $\begin{array}{l}0.025 \\
(1.47)\end{array}$ \\
\hline EarnVol & $\begin{array}{l}0.000 \\
(0.00)\end{array}$ & $\begin{array}{l}0.000 \\
(3.70)\end{array}$ & $\begin{array}{l}0.000 \\
(0.13)\end{array}$ \\
\hline NegEarn & $\begin{array}{l}0.106 \\
(3.05)\end{array}$ & $\begin{array}{l}0.052 \\
(0.92)\end{array}$ & $\begin{array}{l}-0.054 \\
(-0.87)\end{array}$ \\
\hline NegBV & $\begin{array}{l}-0.173 \\
(-1.79)\end{array}$ & $\begin{array}{l}0.039 \\
(0.29)\end{array}$ & $\begin{array}{l}0.212 \\
(1.21)\end{array}$ \\
\hline Constant & $\begin{array}{l}0.164 \\
(1.93)\end{array}$ & $\begin{array}{l}0.121 \\
(1.44)\end{array}$ & $\begin{array}{l}-0.043 \\
(-0.38)\end{array}$ \\
\hline Industry Indicators & - & - & - \\
\hline $\begin{array}{l}\text { Adjusted } R^{2} \\
\text { Number of Obs. }\end{array}$ & $\begin{array}{l}0.371 \\
2,016\end{array}$ & $\begin{array}{l}0.200 \\
4,013\end{array}$ & $\begin{array}{l}- \\
-\end{array}$ \\
\hline
\end{tabular}
coefficients are tested using a spline regression specification. All other variables are defined in Appendix 1. Tstatistics (in parentheses) are calculated using standard errors clustered at the firm level. 


\section{Table 9}

\section{The influence of analyst forecast dispersion on the relation between the spread in analysts' scenario-based value estimates and absolute valuation errors}

This table presents select coefficients from pooled cross-sectional estimations of the following empirical model:

$$
\begin{gathered}
\mid \text { Unanticipated Return }_{i, t} \mid=\alpha+\text { Industry }_{j}+\text { Quarter }_{t}+\beta_{1} \text { Spread }_{i, t}+\beta_{2} \text { Dispersion }_{i, t}+\beta_{3} \text { Base Return }_{i, t-1} \\
+\beta_{4} \text { Firm Size }_{i, t-1}+\beta_{5} \text { Beta }_{i, t-1}+\beta_{6} \text { IdioRisk }_{i, t-1}+\beta_{7} \text { BTM }_{i, t-1}+\beta_{8} \text { BTM }_{i, t-1} * \text { NegBV V }_{i, t-1}+\beta_{9} \text { Leverage }_{i, t-1} \\
+\beta_{10} \text { Leverage }_{i, t-1} * \operatorname{NegBV}_{i, t-1}+\beta_{11} \text { EarnVol }_{i, t-1}+\beta_{12} \text { NegEarn }_{i, t-1}+\beta_{13} \text { NegBV }_{i, t-1}+\varepsilon_{i, t}
\end{gathered}
$$

The dependent variable is the absolute value of unexpected return realizations $\left(\mid\right.$ Unanticipated Return $\left._{i, t} \mid\right)$, where Unanticipated Return ${ }_{i, t}$ is measured as the firm's realized raw return $\left(\right.$ Raw Return $\left._{i, t}\right)$ minus the forecasted return under the analyst's base case scenario $\left(\right.$ Base Return $\left._{i, t}\right)$. The first and second set of columns present estimations using a measure of analyst earnings forecast dispersion based on the analysts' one-year-ahead and two-year-ahead earnings forecasts (Dispersion_FY1 and Dispersion_FY2), respectively. Industry is an array of nine industry indicator variables based on the firm's GICS sector classification. Quarter is an array of fifteen quarter-specific

\begin{tabular}{|c|c|c|c|c|c|c|c|c|}
\hline Dispersion Variable: & \multicolumn{4}{|c|}{ Dispersion_FY1 $(\mathrm{N}=5,964)$} & \multicolumn{4}{|c|}{ Dispersion_FY2 $(\mathrm{N}=5,960)$} \\
\hline Spread & $\begin{array}{l}0.272 \\
(8.68)\end{array}$ & $\begin{array}{l}0.167 \\
(4.68)\end{array}$ & - & $\begin{array}{l}0.166 \\
(4.71)\end{array}$ & $\begin{array}{l}0.267 \\
(8.51)\end{array}$ & $\begin{array}{l}0.166 \\
(4.66)\end{array}$ & - & $\begin{array}{l}0.167 \\
(4.68)\end{array}$ \\
\hline Determinants & Excluded & Included & Included & Included & Excluded & Included & Included & Included \\
\hline $\begin{array}{l}\text { Industry Indicators } \\
\text { Quarter Indicators }\end{array}$ & $\begin{array}{l}\text { Included } \\
\text { Included }\end{array}$ & $\begin{array}{l}\text { Included } \\
\text { Included }\end{array}$ & $\begin{array}{l}\text { Included } \\
\text { Included }\end{array}$ & $\begin{array}{l}\text { Included } \\
\text { Included }\end{array}$ & $\begin{array}{l}\text { Included } \\
\text { Included }\end{array}$ & $\begin{array}{l}\text { Included } \\
\text { Included }\end{array}$ & $\begin{array}{l}\text { Included } \\
\text { Included }\end{array}$ & $\begin{array}{l}\text { Included } \\
\text { Included }\end{array}$ \\
\hline Adjusted $\mathrm{R}^{2}$ & 0.153 & 0.218 & 0.202 & 0.218 & 0.155 & 0.217 & 0.202 & 0.217 \\
\hline
\end{tabular}
indicator variables. All other variables are defined in Appendix 1. T-statistics (in parentheses) are calculated using standard errors clustered at the firm level. 


\section{Table 10}

\section{The relative predictive ability of the spread in analysts' scenario-based value estimates and} volatility indicators for absolute base case valuation errors

This table presents select coefficients from pooled cross-sectional estimations of the following empirical model:

$$
\begin{aligned}
& \mid \text { Unanticipated Return }_{i, t} \mid=\alpha+\text { Industry }_{j}+\text { Quarter }_{t}+\beta_{1} \text { Spread }_{i, t}+\beta_{2} \text { Volatility Flag }_{i, t}+\beta_{3} \text { Base Return }_{i, t-1} \\
& +\beta_{4} \text { Firm Size }_{i, t-1}+\beta_{5} \text { Beta }_{i, t-1}+\beta_{6} \text { IdioRisk }_{i, t-1}+\beta_{7} \text { BTM }_{i, t-1}+\beta_{8} \text { BTM }_{i, t-1} * N e g B V_{i, t-1}+\beta_{9} \text { Leverage }_{i, t-1} \\
& +\beta_{10} \text { Leverage }_{i, t-1} * N e g B V_{i, t-1}+\beta_{11} \text { EarnVol }_{i, t-1}+\beta_{12} \operatorname{NegEarn}_{i, t-1}+\beta_{13} \operatorname{NegBV}_{i, t-1}+\varepsilon_{\mathrm{i}, t}
\end{aligned}
$$

The dependent variable is the absolute value of unexpected return realizations $\left(\mid\right.$ Unanticipated Return $\left._{i, t} \mid\right)$, where Unanticipated Return ${ }_{i, t}$ is measured as the firm's realized raw return $\left(\right.$ Raw Return $\left.n_{i, t}\right)$ minus the forecasted return under the analyst's base case scenario $\left(\right.$ Base Return $\left._{i, t}\right)$. The indicator variable Volatility Flag ${ }_{i, t}$ equals one if the analyst had an outstanding "volatility flag" on the stock at the time the investment report is issued, zero otherwise. The first and second set of columns presents estimations using all available data (Q1 2007 to Q3 2008) and the first three quarters of 2007, respectively. Industry is an array of nine industry indicator variables based on the firm's

\begin{tabular}{|c|c|c|c|c|c|c|c|c|}
\hline Dispersion Variable: & \multicolumn{4}{|c|}{ All Available Reports $(n=2,016)$} & \multicolumn{4}{|c|}{ Reports issued Q1 through Q3 $2007(n=557)$} \\
\hline Spread & $\begin{array}{l}0.188 \\
(7.76)\end{array}$ & $\begin{array}{l}0.116 \\
(4.67)\end{array}$ & - & $\begin{array}{l}0.117 \\
(4.68)\end{array}$ & $\begin{array}{l}0.293 \\
(3.75)\end{array}$ & $\begin{array}{l}0.220 \\
(3.12)\end{array}$ & - & $\begin{array}{l}0.221 \\
(3.11)\end{array}$ \\
\hline Determinants & Excluded & Included & Included & Included & Excluded & Included & Included & Includec \\
\hline $\begin{array}{l}\text { Industry Indicators } \\
\text { Quarter Indicators }\end{array}$ & $\begin{array}{l}\text { Included } \\
\text { Included }\end{array}$ & $\begin{array}{l}\text { Included } \\
\text { Included }\end{array}$ & $\begin{array}{l}\text { Included } \\
\text { Included }\end{array}$ & $\begin{array}{l}\text { Included } \\
\text { Included }\end{array}$ & $\begin{array}{l}\text { Included } \\
\text { Included }\end{array}$ & $\begin{array}{l}\text { Included } \\
\text { Included }\end{array}$ & $\begin{array}{l}\text { Included } \\
\text { Included }\end{array}$ & $\begin{array}{l}\text { Includec } \\
\text { Includec }\end{array}$ \\
\hline Adjusted $\mathrm{R}^{2}$ & 0.402 & 0.422 & 0.412 & 0.422 & 0.145 & 0.208 & 0.190 & 0.209 \\
\hline
\end{tabular}
GICS sector classification. Quarter is an array of fifteen quarter-specific indicator variables. All other variables are defined in Appendix 1. T-statistics (in parentheses) are calculated using standard errors clustered at the firm level. 